Article

\title{
Polyphenolic Fraction from Olive Mill Wastewater: Scale-Up and in Vitro Studies for Ophthalmic Nutraceutical Applications
}

\author{
Maria Domenica Di Mauro ${ }^{1, *}$, Giovanni Fava ${ }^{1}$, Marcella Spampinato ${ }^{1}$, Danilo Aleo ${ }^{2}$, \\ Barbara Melilli ${ }^{2}$, Maria Grazia Saita ${ }^{2}$, Giovanni Centonze ${ }^{3}$, Riccardo Maggiore ${ }^{3}$ \\ and Nicola $D^{\prime}$ Antona ${ }^{1, *}$ (D) \\ 1 National Research Council of Italy, Institute of Biomolecular Chemistry (CNR-ICB), Via Paolo Gaifami 18, \\ 95126 Catania, Italy; giovanni.fava@hotmail.com (G.F.); spampinatomarcella@gmail.com (M.S.) \\ 2 MEDIVIS, Corso Italia, 171, 95127 Catania, Italy; danilo.aleo@medivis.it (D.A.); \\ barbara.melilli@medivis.it (B.M.); mariagrazia.saita@medivis.it (M.G.S.) \\ 3 Envisep srl-Z.Ind. VIII Strada, 29-95121 Catania, Italy; laboratorio@acimgroup.it (G.C.); \\ riccardo.maggiore@libero.it (R.M.) \\ * Correspondence: mariadomenica.dimauro@virgilio.it (M.D.D.M.); nicola.dantona@icb.cnr.it (N.D.); \\ Tel.: +39-095-733-8342 (M.D.D.M. \& N.D.)
}

Received: 2 September 2019; Accepted: 4 October 2019; Published: 8 October 2019

\begin{abstract}
The valorization of food wastes is a challenging opportunity for a green, sustainable, and competitive development of industry. Approximately 30 million $\mathrm{m}^{3}$ of olive mill wastewater (OMWW) are produced annually in the world as a by-product of the olive oil extraction process. In addition to being a serious environmental and economic issue because of their polluting load, OMWW can also represent a precious resource of high-added-value molecules such as polyphenols that show acclaimed antioxidant and anti-inflammatory activities and can find useful applications in the pharmaceutical industry. In particular, the possibility to develop novel nutraceutical ophthalmic formulations containing free radical scavengers would represent an important therapeutic opportunity for all inflammatory diseases of the ocular surface. In this work, different adsorbents were tested to selectively recover a fraction that is rich in polyphenols from OMWW. Afterward, cytotoxicity and antioxidant/anti-inflammatory activities of polyphenolic fraction were evaluated through in vitro tests. Our results showed that the fraction $(0.01 \%)$ had no toxic effects and was able to protect cells against oxidant and inflammatory stimulus, reducing reactive oxygen species and TNF- $\alpha$ levels. Finally, a novel stable ophthalmic hydrogel containing a polyphenolic fraction $(0.01 \%)$ was formulated and the technical and economic feasibility of the process at a pre-industrial level was investigated.
\end{abstract}

Keywords: olive mill wastewater; polyphenols; valorization; adsorbents; ophthalmic hydrogel; anti-inflammatory and antioxidant activity

\section{Introduction}

Olive mill wastewater (OMWW) is a complex mixture of vegetation waters, soft tissues of the olive fruit, and water used during the various stages of the olive oil extraction process, characterized by its dark color, strong odor, a mildly acidic $\mathrm{pH}$, and a very high inorganic and organic load [1,2]; in particular, the organic content (biochemical oxygen demand BOD 35-132 g/L, chemical oxygen demand (COD) 30-320 g/L) [3] consists essentially of sugars, tannins, polyphenols, polyalcohols, proteins, organic acids, pectins, and lipids [4].

In general, the high polyphenolic content (0.5-24 g/L) [5] makes OMWW difficult to biodegrade and a serious environmental and economic issue. Several methods are reported in the literature 
concerning the treatment and disposal of OMWW such as anaerobic digestion, aerobic fermentation, and composting, but all of them involve the loss or destruction of many functional compounds [6-8]. On the other hand, polyphenolic compounds, well-known for their beneficial effects on human health, due to their antioxidant, cardioprotective, anticancer, anti-inflammatory, and antimicrobial properties $[9,10]$ are nowadays widely recognized as valuable molecules in pharmaceutical and nutraceutical fields [11], and in such a context, OMWW represents a really challenging bioresource.

In particular, several studies have highlighted that hydroxytyrosol, the most abundant biophenol in OMWW acts as a free radical-scavenger and metal-chelator [12], protects against oxidative damage [13,14], inhibits the NADPH oxidase [15], the inducible form of nitric oxide synthase (iNOS), and the proinflammatory enzymes such as 5-lipoxygenase and cyclooxygenase [16], decreasing the production of nitric oxide, leukotrienes, and prostaglandins. Moreover, hydroxytyrosol is able to modulate the release of tumor necrosis factor- $\alpha$ (TNF- $\alpha)$ and other proinflammatory mediators $[17,18]$.

Recent studies have reported that oxidative stress is involved in the pathogenesis of several eye diseases, such as ocular inflammation and dry eye disorder $[19,20]$, therefore polyphenols could play an important role in the prevention and/or treatment of these pathologies [21].

Membrane separation, solvent extraction, resins treatment, centrifugation, chromatographic procedures, and enzymatic reactions [22-25] are different strategies reported in the literature to recover polyphenolic compounds from OMWW even if each of them presents a number of issues concerning both the industrial scalability and/or the economic and environmental sustainability.

In this paper we describe a novel route to selectively recover a polyphenolic fraction from OMWW, through a green and sustainable adsorption/desorption batch procedure, the scaling-up of the process at a pre-industrial level, and the in vitro studies to evaluate the cytotoxicity, antioxidant, and anti-inflammatory activities aimed to the formulation of a novel ophthalmic nutraceutical.

\section{Materials and Methods}

\subsection{Materials}

Fresh olive mill wastewater (OMWW) from Cerasuola cultivar were freshly collected in Menfi (Agrigento, Italy) in the middle-late of the olive oil processing season from a continuous three-phase olive oil processing mill operating at a malaxing temperature of $27^{\circ} \mathrm{C}$; samples were stored in airtight screw-capped tanks at $-20^{\circ} \mathrm{C}$.

Folin-Ciocalteu reagent, trifluoroacetic acid (TFA), 3-[4,5-dimethyl(thiazol-2-yl)-3,5diphenyltetrazolium bromide (MTT), 2', 7'-dichlorofluorescein diacetate (DCFH-DA), lipopolysaccharide (LPS) and all standards were purchased from Sigma-Aldrich (Milan, Italy). All solvents were purchased from Carlo Erba (Milan, Italy). The adsorbents Purosorb ${ }^{\mathrm{TM} P A D 428, ~ P u r o s o r b}{ }^{\mathrm{TM} P A D 550,}$ and

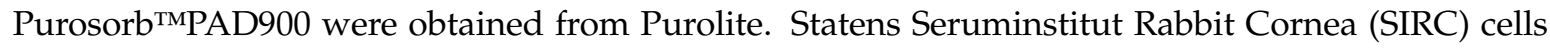
were purchased from the American Type Culture Collection (Rockville, MD, USA). Fetal Bovine Serum (FBS), Eagle's Minimum Essential Medium (EMEM), Phosphate Buffered Saline solution (PBS), and Penicillin-Streptomycin (5000 U/mL) were obtained from Gibco-BRL Life Technologies. Escherichia coli Formamidopyrimidine-DNA Glycosylase (Fpg) FLARE ${ }^{\mathrm{TM}}$ Module (4040-100-FM) was purchased from Trevigen. Rabbit Anti-TNF alpha antibody, Rabbit Anti-beta Actin antibody and Goat Anti-Rabbit IgG H\&L (HRP) were purchased from Abcam. Super Signal West Pico Chemiluminescence detection system was purchased from Thermo Scientific (Rockford, IL, USA). The SkinEthic ${ }^{\mathrm{TM}}$ HCE (human corneal epithelium) tissues were purchased from Episkin (Lyon, France).

\subsection{OMWW Pretreatment}

Cerasuola-OMWW samples were centrifuged at $4000 \mathrm{rpm}(2688 \mathrm{~g}$ ) for $20 \mathrm{~min}$ to remove any solid residues of drupes and leaves and the supernatant was filtered through filter paper under vacuum condition as reported by Fava et al. (2017) [26]. Filtered OMWW were subjected to a flash-freezing process to avoid degradation of polyphenolic compounds and to ensure long-term stability and 
reproducibility of analyses. Samples stored at $-20^{\circ} \mathrm{C}$ into airtight screw-capped containers showed good stability for over 1 year; all analytical operations were performed, when possible, under argon or nitrogen as suggested by Obied et al. (2005) [27], and samples were treated preventing any alterations or contaminations by the environment.

\subsection{Adsorption/Desorption Treatment}

An aliquot of the chosen adsorbing material (Purosorb ${ }^{\text {TMPAD428, Purosorb }}{ }^{\text {TMPAD900, and }}$

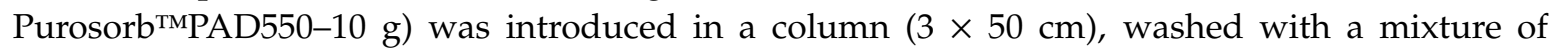
acetone/water (50/50) and then rinsed with water; bed column volumes amounted to $14 \mathrm{~mL}, 11 \mathrm{~mL}$, and $15 \mathrm{~mL}$ respectively for Purosorb ${ }^{\text {TMPAD428, Purosorb }}{ }^{\text {TMPAD900, and Purosorb }}{ }^{\text {TMPAD550. The column }}$ was charged with filtered OMWW $(10 \mathrm{~mL})$ and eluted with pure water $(50 \mathrm{ml})$ to collect the unabsorbed fraction. Subsequently, $50 \mathrm{~mL}$ of the chosen eluent was used to elute the column. Preliminarily different organic eluents or water/organic eluent mixtures were tested for polyphenols desorption, including methanol, ethanol, tetrahydrofuran, and ethyl acetate; in all cases, the best results were obtained with a water/ethanol (50/50) solution with a flow of $0.5 \mathrm{~mL} / \mathrm{min}$. The evaluation of maximum adsorption capacity for each resin was achieved by increasing the OMWW load volume. In order to be regenerated after use, the adsorbents were washed with ethanol $(50 \mathrm{~mL})$, dried, and kept at ambient temperature. Adsorbents were tested by consecutive adsorption/desorption cycles to define their recycling features.

\subsection{Determination of Total Phenol Content}

Total phenols were determined according to Di Mauro et al. (2017) [28]. Microplate spectrophotometer reader (Synergy HT multi-mode microplate reader, BioTek, Milano, Italy) was used to determinate the absorbance at $\lambda 750 \mathrm{~nm}$, and values compared against a gallic acid calibration curve $\left(y=0.002 x+0.030, R^{2}=0.9997\right)$. Results were expressed as $\mathrm{g} / \mathrm{L}$ of gallic acid.

\subsection{Determination of Total Carbohydrates}

Total carbohydrates were determined by the Dubois method [29]. The absorbance values were evaluated at $490 \mathrm{~nm}$ and compared against a glucose calibration curve $\left(R^{2}=0.999\right)$ from 1 to $100 \mathrm{mg} / \mathrm{L}$ (Cary UV Agilent Technology). Results were expressed as mg/L of glucose.

\subsection{Determination of the Pollutant Load}

Evaluation of the pollutant load of OMWW and eluted fractions was performed according to EPA (U.S. Environmental Protection Agency) methods by the following parameters: Chemical oxygen demand (COD, EPA test Method 410.3), biochemical oxygen demand (BOD5, EPA test Method 5210), total phosphorous (EPA test Method 365.3) and total nitrogen (EPA test Method 352.1).

\subsection{Chromatographic Analysis of Polyphenols}

HPLC-DAD (HITACHI) using a Kinetex C-18 $(4.6 \times 250 \mathrm{~mm}, 5 \mu \mathrm{M})$ column (Phenomenex) with a security guard cartridge (Phenomenex) was used for the analytic separation of polyphenols. The column temperature was maintained at $30{ }^{\circ} \mathrm{C}$. Water (A) and acetonitrile (B) were used as eluents, both added with $0.1 \%$ trifluoroacetic acid (TFA). Samples were eluted according to the following gradient: 100\% A as starting condition for $5 \mathrm{~min} ; 58 \% \mathrm{~A}$ in $25 \mathrm{~min} ; 100 \% \mathrm{~B}$ in $15 \mathrm{~min}$, maintained for $5 \mathrm{~min}$; flow rate $0.8 \mathrm{~mL} / \mathrm{min}$. Chromatograms were acquired at $280 \mathrm{~nm}$. Identification of polyphenols was performed by comparison of UV spectra and retention times with the corresponding analytical standards: hydroxytyrosol, tyrosol, 1,2-dihydroxybenzene, oleuropein, 3-(4-hydroxyphenyl)propionic acid, syringic acid, 4-hydroxyphenylacetic acid (PHPA), 4-hydroxybenzoic acid, p-coumaric acid, trans-ferulic acid, gallic acid monohydrate, vanillic acid, caffeic acid, and verbascoside. For each commercial standard a 5-points calibration curve was used for the quantification. 


\subsection{H-NMR Analysis}

Bruker Avance TM 400 spectrometer at $400.13 \mathrm{MHz}$ was used to record ${ }^{1} \mathrm{H}-\mathrm{NMR}$ spectra. All previously dried samples were solubilized in deuterium oxide $\left(\mathrm{D}_{2} \mathrm{O}\right)$. Chemical shifts $(\delta)$ are given as parts per million relative to the residual solvent peak.

\subsection{Adsorption Equilibrium Tests}

Six different aliquots of the adsorbent material were weighted and placed in six beakers, to which $25 \mathrm{ml}$ of OMWW were added. The quantities of adsorbent material were chosen in such a manner that the six beakers contained an adsorbent mass to OMWW volume ratio equal to 1:12, 1:10, 1:8, 1:6, 1:4, and 1:2, respectively. Thus the weighted masses of adsorbent were, in all cases, $2.08 \mathrm{~g}, 2.5 \mathrm{~g}, 3.12 \mathrm{~g}$, $4.17 \mathrm{~g}, 6.25 \mathrm{~g}$, and $12.5 \mathrm{~g}$. The mixtures were stirred for $2 \mathrm{~h}$ and then let rest overnight, at $20{ }^{\circ} \mathrm{C}$ and in darkness, in order to reach the adsorption equilibrium. Samples were then filtered on $0.45 \mu \mathrm{M}$ filters and analyzed for their content in Total Polyphenols and COD.

\subsection{Adsorption Kinetic Tests}

A weighted aliquot of adsorbent was placed in a beaker together with a proper volume of OMWW and subjected to continuous stirring. The adsorbent mass to the OMWW volume ratio, chosen on the base of previously obtained equilibrium adsorption data, was $10 \mathrm{~g}$ of adsorbent for $50 \mathrm{~mL}$ of OMWW. Small aliquots of the mixture ( $1 \mathrm{~mL}$ each) were sampled at predetermined time intervals, and analyzed for their total polyphenols content.

\subsection{Cycling Efficiency Tests}

A weighted aliquot of adsorbent was placed in a beaker together with a proper volume of OMWW and subjected to continuous stirring. The adsorbent mass to OMWW volume ratio, as in the kinetic tests, was 1:5. After a time of $30 \mathrm{~min}$ the mixture was filtered on a porous septum, the filtrate was collected, and the adsorbent was washed with water and placed again in the beaker, this time together with a hydroalcoholic solution (50\% ethanol). After $15 \mathrm{~min}$ of stirring, this mixture was filtered, collected the filtrate phase, and then washed the adsorbent with water, to submit it to a new cycle. This sequence of operations was repeated 5 times. Total polyphenols concentration was determined in all filtrates, calculating the adsorption and desorption efficiency for each cycle.

\subsection{Process Scale-Up}

A prototype pilot plant was developed to scale up the laboratory process. Purosorb ${ }^{\text {TMPAD4}} 28$ was used as an adsorbent phase since it gave the best results in the laboratory phase as described in the "Results and Discussion" section. Since residual oils and sand present in the input waters can cause problems of clogging, accumulation, and eroding or obstructing pipes and machinery, the first stage was the de-oiling and sand removal; a steel tank in which OMWW was released with a flow rate of $0.5 \mathrm{~m}^{3} / \mathrm{h}$ and working simultaneously as a settler and oil-separator was used. De-oiled OMWW was then conveyed into a storage tank, and forced with a flow rate of $300 \mathrm{~L} / \mathrm{h}$, through a sand filter, in order to retain particles with a diameter $>50 \mu \mathrm{M}$ not intercepted in the previous sedimentation step.

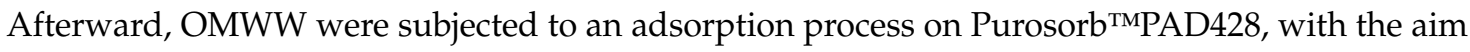
to adsorb polyphenols; the system consisted of a steel vessel with a volume of $100 \mathrm{~L}$, partially filled with $80 \mathrm{~L}$ (about $32 \mathrm{~kg}$ ) Purosorb ${ }^{\mathrm{TM} P A D} 428$. The filtered effluent flowed at a flow rate of $200 \mathrm{~L} / \mathrm{h}$, until $160 \mathrm{~L}$ of water was measured by a flowmeter, in accordance with the OMWW/ Purosorb ${ }^{\text {TMPAD428 }}$ ratio optimized in laboratory tests (5.0 $\mathrm{ml}$ OMWW/g stationary phase).

The obtained de-phenolized OMWW were addressed to a storage tank, which was used for different cosmeceutical applications [30]. After the adsorption phase, pure water was used to wash in countercurrent Purosorb ${ }^{\mathrm{TM}} \mathrm{PAD} 428$. Adsorbed polyphenols were than desorbed with $50 \mathrm{~L}$ water/ethanol/isopropanol 50:42:8 $v / v$ (ethanol/isopropanol 85/15 used to prepare the eluent phase 
represented the purest commercially available composition for semi-industrial use) with a flow rate of $5 \mathrm{~L} / \mathrm{min}$, and stored in a $2000 \mathrm{~L}$ tank. As the last step, Purosorb ${ }^{\mathrm{TM}}$ PAD428 was washed with $50 \mathrm{~L}$ ethanol/isopropanol 85/15, and then with water to eliminate alcoholic residues before restarting the cycle. Analytic control and chemical characterization on outputs from the various steps of the process was achieved by sampling points at various parts of the plant for each cycle sequence.

\subsection{In Vitro Study}

\subsubsection{Cell Cultures and Treatments}

SIRC cells (passage: 18) were cultured in a 12- or 96-multiwell microplate and/or in $25 \mathrm{~cm}^{2}$ flasks, according to the type of assay, with EMEM supplemented with $1 \%$ penicillin-streptomycin and $10 \%$ fetal bovine serum, and incubated under a humidified atmosphere at $37^{\circ} \mathrm{C}$ with $5 \% \mathrm{CO}_{2}$. When cells reached $70 \%$ of confluence, the lyophilized fraction PAD428-FR2 was dissolved in culture medium at the appropriate final concentrations for each biological assay.

\subsubsection{MTT Assay}

The potential cytotoxic effect of fraction was evaluated by MTT assay [30,31] on SIRC cells $(2.5 \times$ $10^{4}$ cells/well) untreated and treated with different concentrations of PAD428-FR2 $(0.01 \%, 0.02 \%, 0.05 \%$, $0.1 \%)$ for $24 \mathrm{~h}$; subsequently, $200 \mu \mathrm{L}$ of MTT $\left(0.5 \mathrm{mg} \mathrm{mL}^{-1}\right)$ in culture medium were added to each well and incubated for $3 \mathrm{~h}$ at $37^{\circ} \mathrm{C}$ keeping a humidified atmosphere with $5 \% \mathrm{CO}_{2}$. Finally, the supernatant was aspirated off and $100 \mu \mathrm{L}$ of DMSO was added to each well to dissolve the formazan crystals.

A microplate spectrophotometer reader (Synergy HT multi-mode microplate reader, BioTek, Milano, Italy) at $\lambda=550 \mathrm{~nm}$ was used to measure the optical density (OD). Results were expressed as a percentage of cell viability with respect to untreated control viable cells, whose value was equal to $100 \%$.

\subsubsection{Lactic Dehydrogenase Release}

Lactic dehydrogenase (LDH) release was evaluated on SIRC cells untreated and treated with different concentrations of PAD428-FR2 $(0.01 \%, 0.02 \%, 0.05 \%, 0.1 \%)$ for $24 \mathrm{~h}$, measuring spectrophotometrically in the culture medium and in the cellular lysates, at $\lambda=340 \mathrm{~nm}$ by analyzing $\mathrm{NADH}$ reduction [32]. The percentage of lactic dehydrogenase release was calculated as the percentage of the total amount, considered as the sum of the enzymatic activity present in the cellular lysate and that in the culture medium.

\subsubsection{Alkaline Comet Assay}

The alkaline comet assay was performed on SIRC cells untreated and treated with PAD428-FR2 $(0.01 \%, 0.02 \%, 0.05 \%)$ for $24 \mathrm{~h}$. The minigels were prepared as described by Tomasello et al. (2017) [33]. Then, as described by Di Mauro et al. (2017) [34], the alkaline version of the comet assay was performed. An analysis of fifty nucleoids for each sample was carried on by using an epifluorescence microscope (Leica, Wetzlar, Germany) equipped with a camera. DNA damage was evaluated by using CASP (1.2.2) image analysis software. Results were expressed as the percentage of fragmented DNA present in the comet tail (\%TDNA).

\subsubsection{Reactive Oxygen Species (ROS) Determination}

ROS levels were evaluated using 2',7'-dichlorofluorescein diacetate [35]. A microplate spectrofluorometer reader (Synergy HT multi-mode microplate reader, BioTek, Milano, Italy) was used to measure the fluorescence ( $\lambda$ excitation $=488 \mathrm{~nm}$ and $\lambda$ emission $=525 \mathrm{~nm}$ ). The total protein content was evaluated for each sample according to Bradford (1976) [36]. The results were expressed as fluorescence intensity per mg protein. 


\subsubsection{Protective Effect against Oxidative Stress}

SIRC cells were pretreated with PAD428-FR2 $0.01 \%$ for $24 \mathrm{~h}$ and then stimulated with $\mathrm{H}_{2} \mathrm{O}_{2}$ $(200 \mu \mathrm{M})$ for 10 and $30 \mathrm{~min}$. Untreated cells were used as negative control; cells treated with $\mathrm{H}_{2} \mathrm{O}_{2}$ $(200 \mu \mathrm{M})$ were used as a positive control. After treatments, cell viability was evaluated by MTT assay as previously described.

The oxidative DNA damage was evaluated by the Fpg-modified comet assay [37]. After lysis, each sample was incubated with $100 \mu \mathrm{L}$ of enzyme dilution buffer or Fpg enzyme solution in a humidity chamber at $37^{\circ} \mathrm{C}$ for $45 \mathrm{~min}$. Then the samples were electrophoresed in alkaline solution (300 $\mathrm{mM}$ $\mathrm{NaOH}, 1 \mathrm{mM} \mathrm{Na}{ }_{2} \mathrm{EDTA}, \mathrm{pH}>13$ ) for $20 \mathrm{~min}$ at $0.7 \mathrm{~V} / \mathrm{cm}$. After staining with SYBR green, the nucleoids were analyzed as already described.

ROS levels were evaluated using 2',7'-dichlorofluorescein diacetate [35] as previously reported.

\subsubsection{Protective Effect against Inflammation}

SIRC cells were pretreated with PAD428-FR2 $0.01 \%$ for $2 \mathrm{~h}$ and then stimulated with lipopolysaccharide (LPS $1 \mu \mathrm{g} / \mathrm{mL}$ ) for $24 \mathrm{~h}$. Untreated cells were used as negative control; cells treated with LPS $(1 \mu \mathrm{g} / \mathrm{mL})$ were used as a positive control. After treatments, cell viability was evaluated by MTT assay as previously described.

TNF- $\alpha$ protein expression was determined by Western Blot analysis. After treatments, proteins were extracted from SIRC cells as described by Anfuso et al. (2017) [38]. Protein samples (30 $\mu \mathrm{g} / \mathrm{lane})$ were subjected to SDS-PAGE and, after transferring to nitrocellulose membranes, were incubated with antibody against TNF- $\alpha$ and $\beta$-actin overnight at $4{ }^{\circ} \mathrm{C}$ followed by incubation with horseradish peroxidase conjugated secondary antibody, goat anti-rabbit for TNF- $\alpha$ and $\beta$-actin. Super Signal West Pico Chemiluminescence detection system was used to visualize the protein expression after washing with TBS-T. $\beta$-actin was used as the loading control. Image J software (Version1.43, Broken Symmetry Software, Bethesda, MD, USA) was used to analyze bands.

\subsection{Studies for Ophthalmic Nutraceutical Application}

\subsubsection{Ophthalmic Formulation and Stability Study}

PAD428-FR2 $0.01 \%$ was formulated in a hydrogel whose composition is shown in Table 1.

Table 1. Composition of the ophthalmic hydrogel.

\begin{tabular}{ll}
\hline \multicolumn{1}{c}{ Ingredients } & \multicolumn{1}{c}{ Composition (\%) } \\
\hline PAD428-FR2 & 0.01 \\
Carbopol $^{\mathrm{R}} 980$ & 0.20 \\
Pemulen $^{\mathrm{TM}} \mathrm{RT} 1-\mathrm{NF}$ & 0.01 \\
EDTA & 0.02 \\
Glycerol & 1.15 \\
$\mathrm{Na}_{2} \mathrm{HPO}$ & $\cdot 12 \mathrm{H}_{2} \mathrm{O}$ \\
$\mathrm{NaOH}$ & 0.25 \\
Purified water & 0.07 \\
\hline
\end{tabular}

Initially, three different solutions (A, B, and C) were prepared as described above. Solution A was prepared in an appropriate container $(1 \mathrm{~L})$ by dissolving $11.5 \mathrm{~g}$ of glycerol in $700 \mathrm{~g}$ of purified water. Next, $2 \mathrm{~g}$ of Carbopol ${ }^{\circledR} 980$ and $0.1 \mathrm{~g}$ of Pemulen ${ }^{\mathrm{TM}} \mathrm{RT} 1-\mathrm{NF}$ were added to the previous solution left under stirring for $2 \mathrm{~h}$ to ensure the complete dissolution of polymers. The resulting solution was sterilized in autoclave at $121^{\circ} \mathrm{C}$ for $20 \mathrm{~min}$. Solution B was prepared by dissolving $2.5 \mathrm{~g}$ of $\mathrm{Na}_{2} \mathrm{HPO}_{4} 12 \mathrm{H}_{2} \mathrm{O}$ and $0.7 \mathrm{~g}$ of $\mathrm{NaOH}$ in $200 \mathrm{~g}$ of purified water. Solution $\mathrm{C}$ was obtained by dissolving $0.2 \mathrm{~g}$ of EDTA and $0.10 \mathrm{~g}$ of lyophilized PAD428-FR2 in $79.7 \mathrm{~g}$ of purified water. Both solutions $\mathrm{B}$ and $\mathrm{C}$ were filtered through a hydrophilic filter PES Durapore $0.22 \mu \mathrm{M}$ in a sterile environment 
and transferred into glass containers preliminarily sterilized. Solution B was added dropwise to the polymeric solution (A) stirring for $30 \mathrm{~min}$. Finally, solution $\mathrm{C}$ was added to the obtained gel stirring for $60 \mathrm{~min}$. The formulation was divided into $2 \mathrm{~mL}$ sterile polypropylene vials with screw cap and "O" silicone ring (Axygen $\left.{ }^{\circledR}\right)$. All operations were carried out at $25^{\circ} \mathrm{C}$ and in particular the process of filtration and closure was performed under sterile condition using a vertical laminar flow cabinet with HEPA filters (Bio Activa Plus, Aquaria ${ }^{\circledR}$ ).

The $\mathrm{pH}$, osmolality, appearance, and hydroxytyrosol concentration (\%) were evaluated on different aliquots of hydrogel stored in dark conditions into $2 \mathrm{~mL}$ sterile polypropylene vials at $25 \pm 2{ }^{\circ} \mathrm{C}$ with $60 \% \pm 5 \%$ relative humidity (R.H.) for 3 months.

\subsubsection{Ocular Irritation Test}

The ocular irritation potential of the formulation was evaluated by using SkinEthicTM HCE model according to the protocol and instructions of the manufacturer. Positive (ethanol-treated) and negative (PBS-treated) controls were used. The tissues were evaluated for cell viability (CV) using the MTT assay [39]. If the percentage of CV was $>60 \%$, the substance can be predicted as non-irritant (UN GHS classification: no category); if the percentage of $\mathrm{CV}$ was $\leq 60 \%$, the substance can be considered irritant (UN GSH classification: Category 1 or Category 2).

\subsection{Statistical Analysis}

All results were obtained by three independent experiments performed in triplicate; the means and standard deviations for each value were calculated. One way ANOVA was used to assess statistical differences among different treatments. Bonferroni test was performed to obtain post hoc comparison. $p<0.05$ as minimum level of significance was applied. Graph Prism version 5 and/or Microsoft Excel was used to perform all the analyses.

\section{Results and Discussion}

\subsection{Selective Recovery of Polyphenolic Fraction from OMWW}

Cerasuola-OMWW characterization was performed as described in previous works [26,28] and results are summarized in Table 2 .

Table 2. Chemical characterization of olive mill wastewater (OMWW) and fractions.

\begin{tabular}{llllll}
\hline \multicolumn{1}{c}{ Characterization } & \multicolumn{1}{c}{ OMWW } & PAD428-FR1 & PAD900-FR1 & PAD428-FR2 & PAD900-FR2 \\
\hline Total Nitrogen (mg/L) & $350.0 \pm 3.4$ & $318.0 \pm 3.1$ & $320.0 \pm 3.2$ & $1.0 \pm 0.2$ & $1.0 \pm 0.2$ \\
Total Phosphorous (mg/L) & $186.0 \pm 2.1$ & $144.0 \pm 2.3$ & $149.0 \pm 2.1$ & $0.5 \pm 0.01$ & $0.5 \pm 0.01$ \\
COD (g/L) & $73.65 \pm 1.43$ & $44.80 \pm 1.34$ & $44.02 \pm 1.55$ & $20.42 \pm 1.25$ & $21.07 \pm 1.29$ \\
BOD5 (g/L) & $38.44 \pm 2.12$ & $26.42 \pm 2.05$ & $26.40 \pm 2.19$ & $15.60 \pm 1.99$ & $15.33 \pm 1.92$ \\
Total Polyphenols (g/L) & $5.20 \pm 0.14$ & $0.40 \pm 0.04$ & $0.38 \pm 0.04$ & $4.12 \pm 0.11$ & $3.94 \pm 0.12$ \\
Hydroxytyrosol (g/L) & $1.10 \pm 0.08$ & - & - & $0.90 \pm 0.06$ & $0.85 \pm 0.06$ \\
Tyrosol (g/L) & $0.14 \pm 0.02$ & - & - & $0.10 \pm 0.02$ & $0.08 \pm 0.01$ \\
Total Sugar (g/L) & $34.00 \pm 2.18$ & $24.22 \pm 1.14$ & $23.75 \pm 2.09$ & $4.70 \pm 0.59$ & $4.82 \pm 0.32$ \\
\hline
\end{tabular}

Mean values $(n=9) \pm$ SD were calculated.

A valuable use of olive mill wastewaters could be obtained through the valorization of the recovered polyphenolic fraction. Practically, this is a hard task since biophenols are not very stable and can easily get oxidized, hydrolyzed, polymerized, conjugated, and/or complexated in this aqueous environment containing all the reactants (such as metals, enzymes, oxygen, and polysaccharides), required for these kinds of transformations. In a preliminary attempt to identify new, eco-sustainable, and cheaper materials, that are able to selectively adsorb the phenolic fraction (or a fraction of it), three "untraditional" materials were tested: corncob (the maize central core), coffee husk (a waste of the coffee torrefaction process), and volcanic ashes. These materials were chosen both because of their 
abundant presence in Sicily, and since they constitute wastes (in the case of volcanic ashes, wastes generated by nature itself), and were characterized by relevant disposal costs and/or polluting issues. All tested processes with these materials, regardless of the used conditions, did not give any significant results showing no selective or unselective adsorption property toward the compounds contained in OMWW. In a further attempt, three different commercial polymeric adsorbents (Purosorb ${ }^{\mathrm{TM}}$ PAD428,

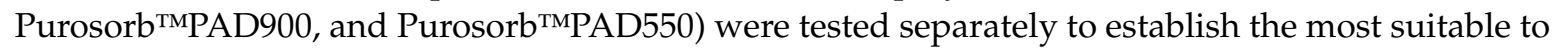
retain completely or partially the phenolic fraction in a selective way.

Different eluents and values of flow or temperature were tested to find a good compromise that would allow the ability to minimize possible oxidation reactions and achieve equilibria between the various phases. The general best conditions were a flow of $0.5 \mathrm{~mL} / \mathrm{min}$ at $22{ }^{\circ} \mathrm{C}$, and elution with water, to collect the unabsorbed fraction (FR1), followed by a solution of water/ethanol (50/50) in the attempt to selectively desorb the polyphenolic fraction (FR2), and finally with pure ethanol to wash and recycle the adsorbent phase. Analysis of different eluted fractions by HPLC-DAD indicated that only Purosorb ${ }^{\mathrm{TM}} \mathrm{PAD} 428$ and Purosorb ${ }^{\mathrm{TM}} \mathrm{PAD} 900$ were able to completely retain the phenolic compounds. In fact, both aqueous fractions (PAD428-FR1 and PAD900-FR1) presented a slight yellow color and were almost completely deprived of any phenolic component as demonstrated both by chromatograms at $280 \mathrm{~nm}$ and by ${ }^{1} \mathrm{H}-\mathrm{NMR}$ spectra (data are shown in Supplementary materials Figures S2-S8); the results reported in Table 2 show that the eluted aqueous fractions (PAD428-FR1 and PAD900-FR1) had a very low amount of polyphenols $(0.40$ and $0.38 \mathrm{~g} / \mathrm{L})$. Furthermore, the values of COD and BOD were reduced by $40 \%$ and $30 \%$ respectively, and a slight decrease in the inorganic load was observed too (Table S1 shown in Supplementary material). On the other hand, high amounts of carbohydrates (not retained by the adsorbent resins) suggest that this fraction could find valuable applications in cosmetic field as described in a recent work [30].

Conversely, the fractions eluted with the ethanolic mixture (PAD428-FR2 and PAD900-FR2) presented an intense red-brown color and gave again similar results in terms of polyphenols content (up to $4.12 \mathrm{~g} / \mathrm{L}$, recovery $80 \%$ ) as shown by the PAD428-FR2 sample chromatogram reported in Figure 1, with hydroxytyrosol and tyrosol respectively $0.90-0.85 \mathrm{~g} / \mathrm{L}$ and $0.10-0.08 \mathrm{~g} / \mathrm{L}$ as reported in Table 2. However other biophenols were identified in PAD428-FR2 samples as shown in Table S2 (see Supplementary materials).

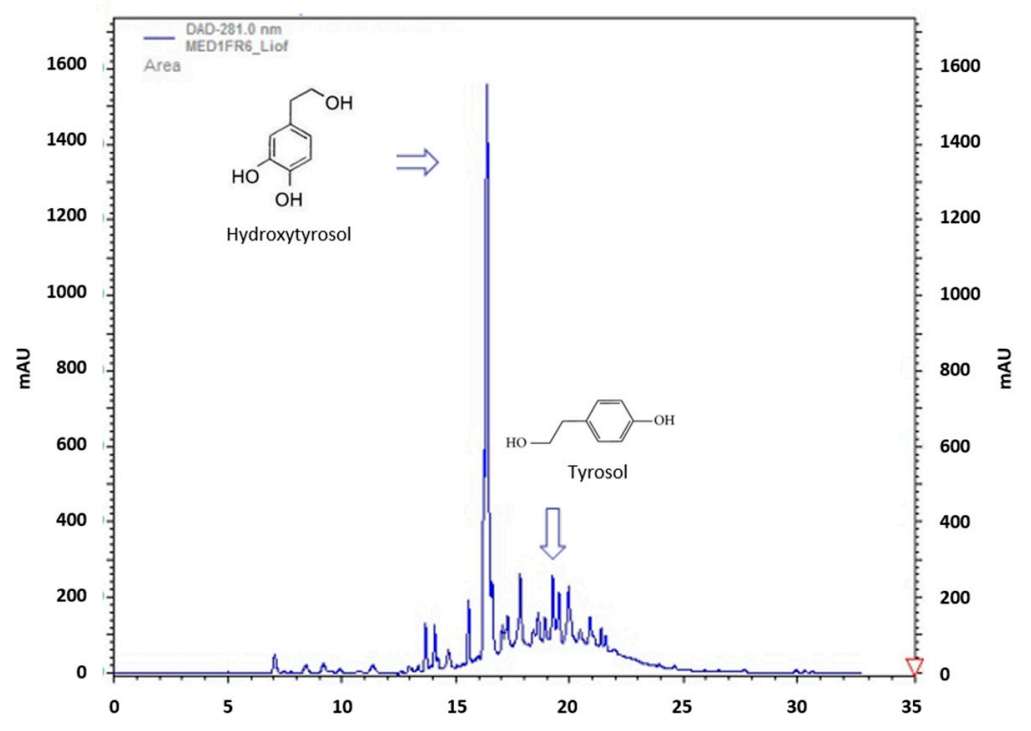

Figure 1. Chromatogram of PAD428-FR2 fraction at $280 \mathrm{~nm}$.

The maximum volume of Cerasuola-OMWW that can be absorbed by $10 \mathrm{~g}$ of both adsorbent resins, before saturation, was $30 \mathrm{~mL}$. Since Purosorb ${ }^{\text {TMPAD428 and Purosorb }}{ }^{\text {TMPAD } 900 ~ s h o w e d ~ v e r y ~ s i m i l a r ~}$ adsorbent features, the subsequent adsorption equilibrium tests and scale-up process were carried out 


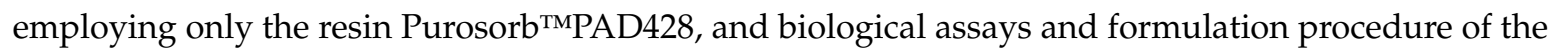
ophthalmic nutraceutical were realized with the corresponding polyphenolic fraction (PAD428-FR2).

\subsection{Adsorption Equilibrium and Kinetic Tests}

To describe the equilibrium state in the adsorption system, the concept of dynamic equilibrium is commonly used. The liquid/gas molecules striking on the surface of a solid material can be adsorbed or rebounded; the rate of adsorption at the beginning is elevated since the adsorption sites are all available, but it decreases over time as the surface gets covered by adsorbate molecules. Conversely, the desorption rate increases because a greater number of molecules rebound until reaching the equilibrium between the adsorption rate and the desorption rate [40]. There are several equilibrium isotherm models but the most used and important in the field of adsorption for environmental cleanup are Freundlich and Langmuir isotherms [41,42].

After adsorption equilibrium was reached, batch test mixtures were filtered (on filter paper) and collected in test tubes. The resulting solutions for Purosorb ${ }^{\mathrm{TM}} \mathrm{PAD} 428$ resin test are shown in Figure 2a. The color diminution, that corresponds to the increase in the adsorbent dose (from right to left), was a clear symptom of the removal of the polyphenolic components (that are accounted for the typical reddish OMWW color). The solutions were analyzed, with respect to their content in COD and total polyphenols, and the results (see Figure 2b) confirmed the visual interpretation.

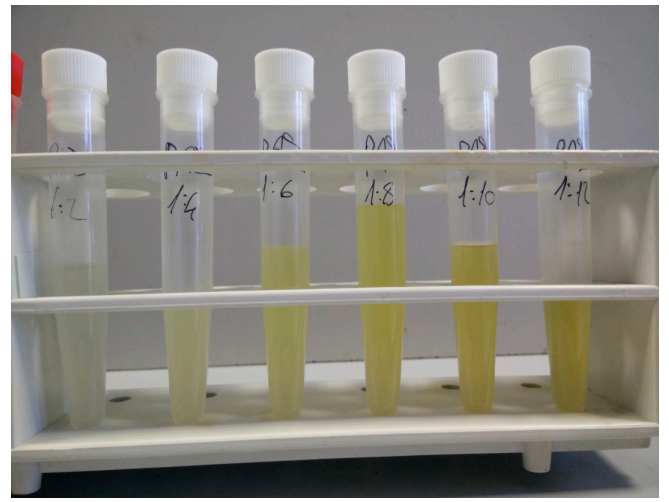

(a)

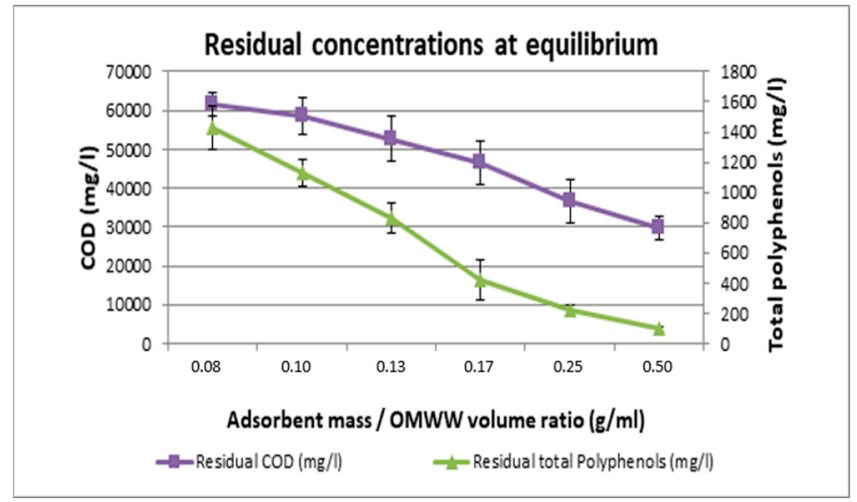

(b)

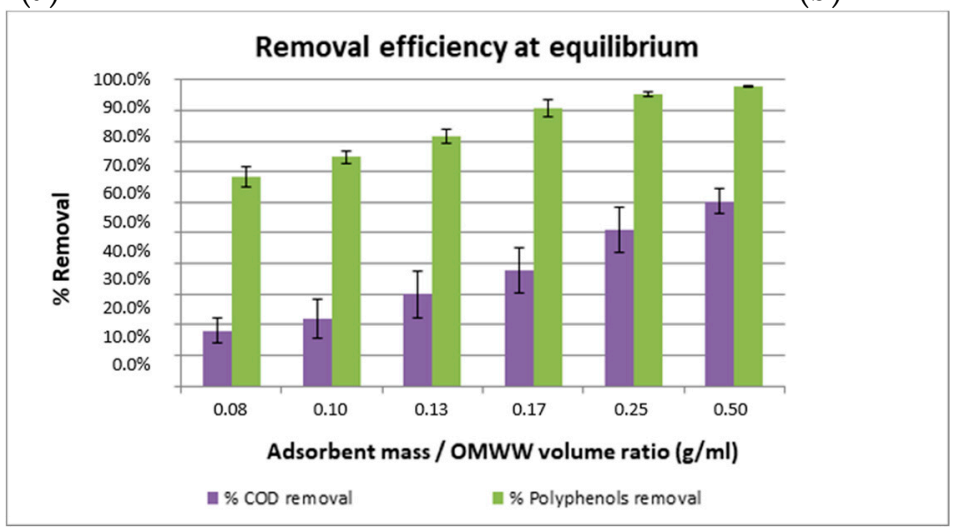

(c)

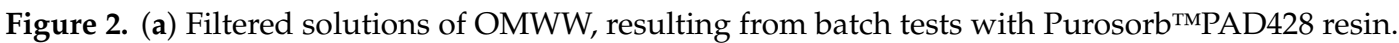
(b) Residual concentrations of chemical oxygen demand (COD) and total polyphenols, at adsorption

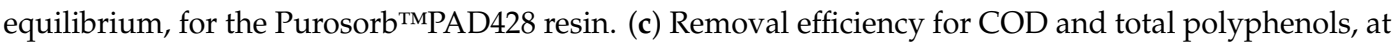
adsorption equilibrium, for the Purosorb ${ }^{\mathrm{TM}} \mathrm{PAD} 428$ resin. Mean values $(n=5) \pm \mathrm{SD}$ were calculated.

According to Figure 2c, a significant increase in total polyphenols removal efficiency was observed when the adsorbent dose to OMWW ratio increased from 1:12 to 1:2. The total polyphenols removal 
reached $90 \%$ at 1:6 ratio $(0.17)$, while the removal rate increase was less pronounced at higher ratios. This result is easily understandable since an increase in the amount of adsorbent material will increase the total surface area and the available adsorption sites, lowering the driving force for intra-particle adsorption at each adsorption site, and resulting in a minor utilization of the adsorption capacity. This leads to the conclusion 1:5 ratio is considered to be a good compromise between removal efficiency and employed quantity of adsorbent.

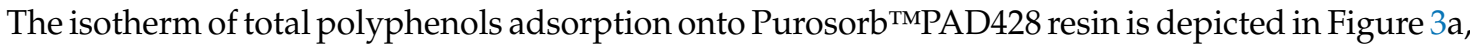
in which the $R^{2}$, associated with the Freundlich model fitting, is indicated. It is observed that the curve is concave downward, indicating a favorable isotherm leading to high adsorption capacity, as depicted in the values of Langmuir constants. In the fixed-bed adsorption column, a strongly favorable isotherm would also lead to a short mass transfer zone [43].

As reported in Figure 3b, a better representation of results is obtained by the Langmuir isotherm model. This was an expected result since, compared to Freundlich isotherm, this model is more flexible in modeling adsorption from highly concentrated water solutions. This result validates the assumption of monolayer homogenous adsorption of total polyphenols on polymeric resin.

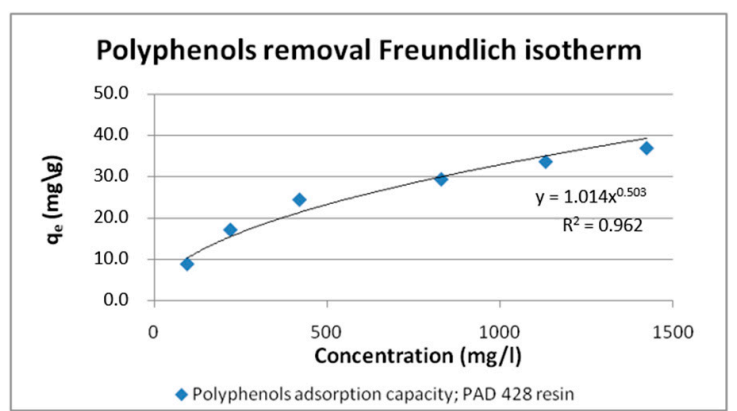

(a)

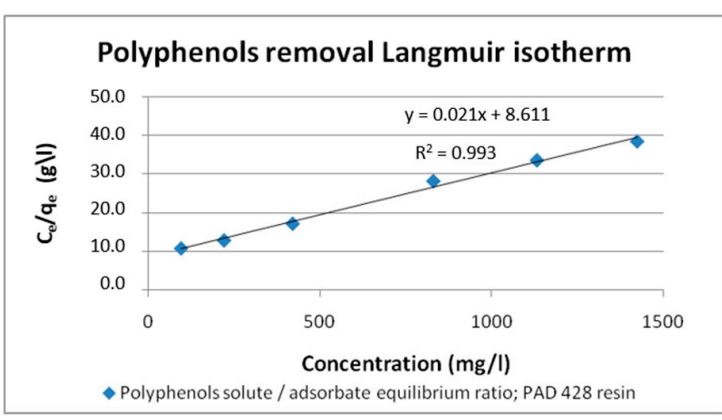

(b)

Figure 3. Freundlich (a) and Langmuir (b) isotherm curve for polyphenols adsorption, at equilibrium, 373 for the Purosorb ${ }^{\mathrm{TM} P A D} 428$ resin. The y-axis reports: for the Freundlich curve, the equilibrium adsorption capacity " $\mathrm{q}_{\mathrm{e}}$ " ( $\mathrm{q}_{\mathrm{e}}=\mathrm{x} / \mathrm{m}$, in which $\mathrm{x}=$ mass of adsorbate and $\mathrm{m}=$ mass of adsorbent); for the Langmuir curve, the " $\mathrm{C}_{\mathrm{e}} / \mathrm{q}_{\mathrm{e}}$ " ratio (in which $\mathrm{C}_{\mathrm{e}}$ is the solute concentration at the equilibrium).

The correlation coefficient $\mathrm{R}^{2}$ shown in Table 3 gives privilege for Langmuir isotherm over Freundlich one. The maximum Langmuir capacity $\mathrm{Q}^{0}$ matches the equilibrium adsorption capacity curve (Figure 3b).

Table 3. Freundlich and Langmuir isotherms constants for total polyphenols adsorption on Purosorb ${ }^{\mathrm{TM}} \mathrm{PAD} 428$ resin.

\begin{tabular}{|c|c|c|c|c|c|}
\hline \multicolumn{3}{|c|}{ Freundlich Isotherm } & \multicolumn{3}{|c|}{ Langmuir Isotherm } \\
\hline$R^{2}$ & $N$ & $K_{F}$ & $R^{2}$ & $Q^{0}$ & $K_{L}$ \\
\hline & & $\left((\mathrm{mg} / \mathrm{g})(\mathrm{L} / \mathrm{mg})^{1 / \mathrm{n}}\right)$ & & & $\mathrm{L} / \mathrm{mg}$ \\
\hline 0.962 & 2.0 & 1.0 & 0.993 & 47.7 & 0.02 \\
\hline
\end{tabular}

Langmuir separation factor $\mathrm{R}_{\mathrm{L}}$ resulted to be equal to 0.084 , indicating that the adsorption isotherm

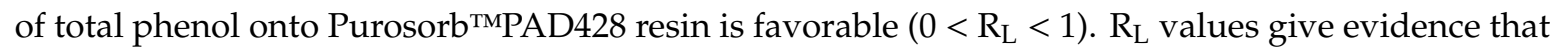
the process is reversible, supporting the hypothesis that physical adsorption occurs in this process.

\subsection{Cycling Efficiency Tests}

One of the topics of adsorption systems is the number of cycles an adsorbent can undergo, which could be a limiting factor for the suitability and the overall economic convenience of the process. 
Cycling tests were performed on Purosorb ${ }^{\text {TMPAD}} 428$ resin and Figure 4 shows results: it is confirmed, for the first cycle, that adsorption efficiency, after a 30 min contact time at 1:5 adsorbent mass to OMWW volume ratio, was about $91 \%$, as found out in previous tests. After each cycle, this value slightly decreased down to about $79 \%$ after five cycles. Concerning the desorption efficiency values, these remained quite constant throughout the several cycles with values between 60-66\%. Surprisingly, the incomplete polyphenols desorption from resin adsorption sites seems not to drastically influence its adsorption efficiency, maybe because it was charged at its maximum capacity during the tests. Anyway, this is an aspect that should be further investigated in future studies.

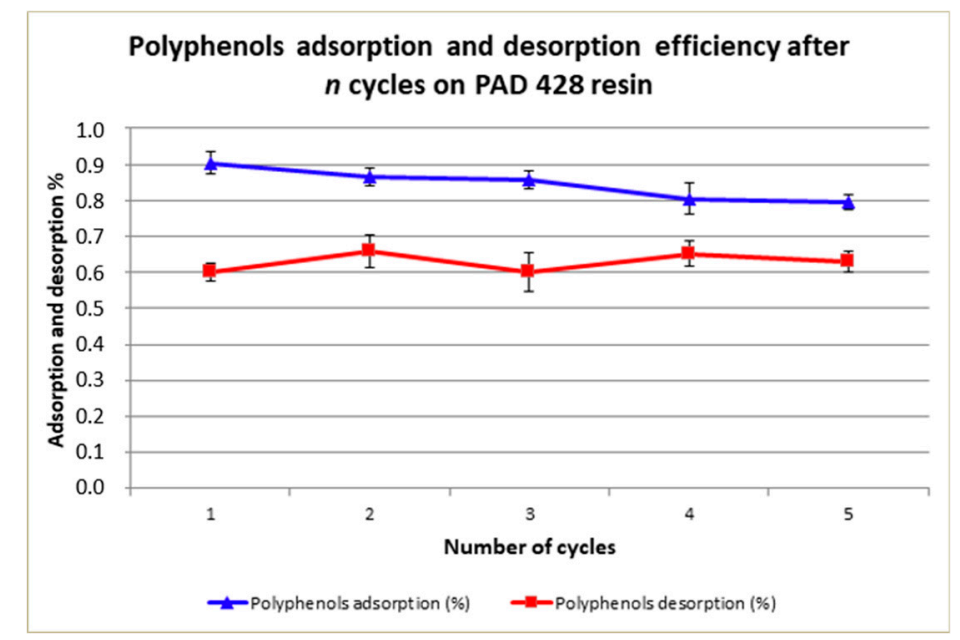

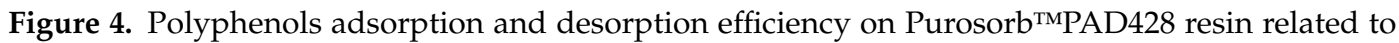
working cycle number. Mean values $(n=5) \pm$ SD were calculated.

Figure 5 reports the overall polyphenols recovery. The recovery efficiency reduction, after five cycles, was of $-7.5 \%$ (from $54 \%$ to $50 \%$ ) for Purosorb ${ }^{\text {TMPAD }} 428$, even if a statistical analysis will be necessary for a better evaluation of data.

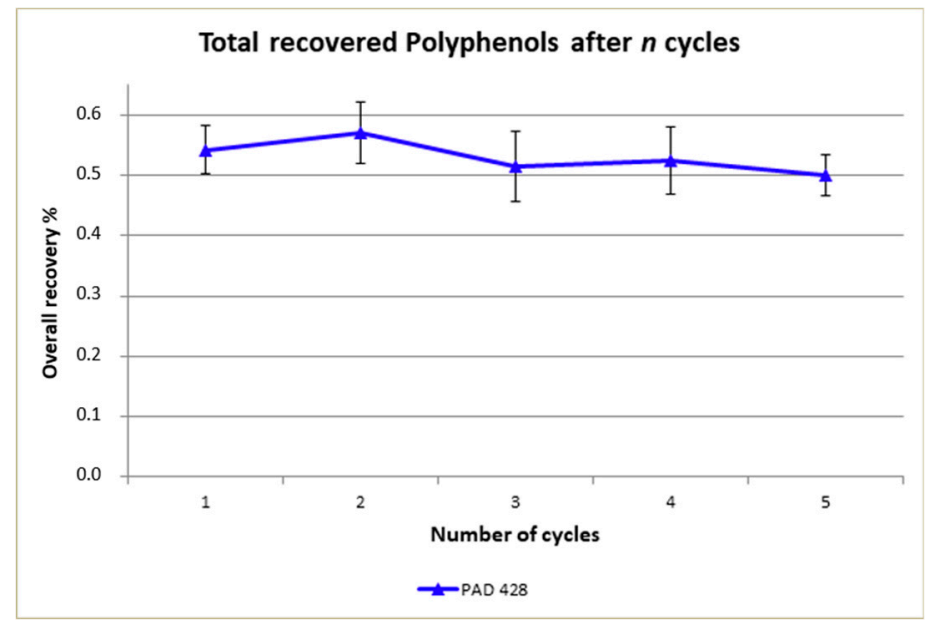

Figure 5. Total polyphenols recovered from OMWW using Purosorb ${ }^{\mathrm{TM}} \mathrm{PAD} 428$, related to the numbers of adsorption/desorption cycles. Mean values $(n=5) \pm$ SD were calculated.

\subsection{In Vitro Study and Ophthalmic Nutraceutical Application}

Even if natural compounds and extracts are commonly considered free from harmful effects possible safety problems cannot be excluded [30]. Generally, irritation and cytotoxicity tests are performed to reduce the ocular risk of exposure to dangerous substances. Historically, animal tests 
such as the in vivo Draize rabbit assay were used to define the level of ocular toxicity by application of a test compound to a live rabbit's eye and then evaluation of the biological response. Recently, several in vitro alternative techniques have been developed as the result of ethical reconsideration of the animal used for toxicology studies [44].

For this purpose, we performed an in vitro study by using SIRC cells, a cell line having a mixed epithelial and fibroblastic nature [45], already used for toxicology studies in ophthalmic field [46,47].

Our preliminary interest was to evaluate in vitro the possible cytotoxic effect elicited by the fraction PAD428-FR2. Figure 6a shows the results of MTT assay, a colorimetric method measuring the reduction of MTT, a yellow-colored tetrazolium salt, to a purple formazan by the mitochondrial dehydrogenase enzyme of living cells [30,32]. The MTT assay data obtained on SIRC cells treated with different concentrations of PAD428-FR2 for 24 hours provided evidence to show that the lowest concentration $(0.01 \%)$ did not influence the cell viability compared to untreated control cells. Conversely, the treatment with higher concentrations $(0.02 \%, 0.05 \%$, and $0.1 \%)$ caused a drastic decrease in cell viability in a dose-dependent manner with respect to both untreated control cells and $0.01 \%$ treated cells; in particular, these concentrations $(0.02 \%, 0.05 \%$, and $0.1 \%)$ were able to induce a dose-dependent necrotic effect as a result of cell membrane disruption (Figure 6b), in accordance with MTT assay data.

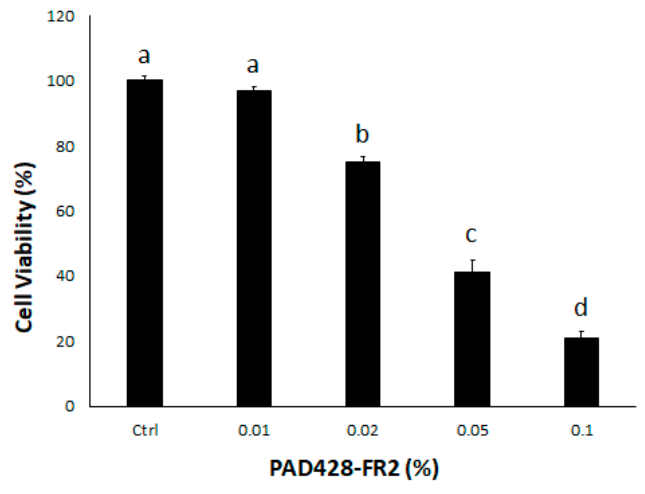

(a)

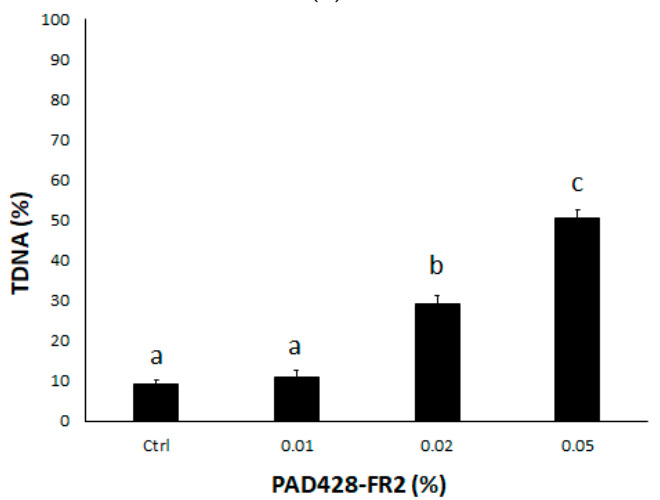

(c)

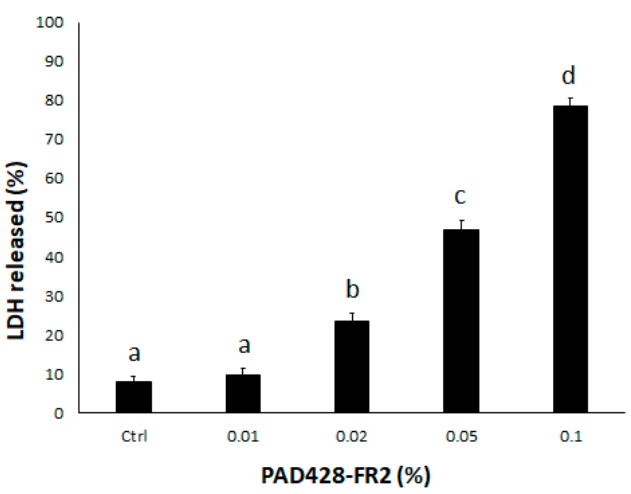

(b)

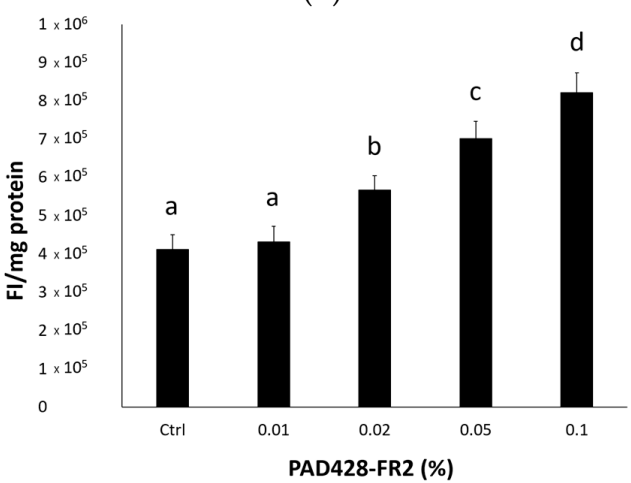

(d)

Figure 6. Effects of PAD428-FR2 on SIRC cells treated for 24 hours. (a) The results of 3-[4,5-dimethyl(thiazol-2-yl)-3,5-diphenyltetrazolium bromide (MTT) assay are expressed as the percentage of cell viability with respect to untreated control cells (Ctrl). (b) Lactic dehydrogenase (LDH) released. (c) DNA damage evaluated by alkaline comet assay; the results are expressed as the percentage of DNA present in the comet tail (\%TDNA). (d) Reactive oxygen species (ROS) levels evaluated spectrofluorometrically by using $2^{\prime}, 7^{\prime}$-dichlorofluorescein diacetate (DCFH-DA); the results are expressed as fluorescence intensity (FI) per mg protein. Values are mean \pm SD of three experiments in triplicate. Bars with different letters are significantly different $(p<0.05)$.

In addition, we evaluated in vitro the potential genotoxic effects of the fraction. Among the different approaches used to study DNA damage, comet assay is a simple and fast method to assess 
different types of DNA damage at the single-cell level [48]. In particular, we performed alkaline comet assay that permits to identify DNA double-strand breaks, single-strand breaks, alkali-labile sites, DNA-DNA/DNA-protein cross-linking, and incomplete excision repair sites [49]. The results, shown in Figure $6 c$, provided evidence that the treatment with $0.02 \%$ and $0.05 \%$ induced DNA damage in a dose-dependent manner.

In order to evaluate the possible mechanism of action, we measured ROS levels by using DCFH-DA, a non-fluorescent molecule that can spread through the cell membrane and, once inside the cell, is enzymatically hydrolyzed by an intracellular esterase to non-fluorescent DCFH; then ROS are able to oxidize DCFH to the fluorescent dichlorofluorescein (DCF), whose fluorescence intensity (FI) is proportional to the level of intracellular ROS [50].

In our opinion, the observed toxic effects could be related to the ROS overproduction (Figure $6 \mathrm{~d}$ ), that can determine the accumulation of oxidized intracellular macromolecules influencing the cell viability up until inducing cell death [51].

Based on these results we decided to continue the study by excluding the highest concentrations (ranging from $0.02 \%$ to $0.1 \%$ ) because of their toxicity for the selected cell line.

It is well known that oxidative stress is involved in the pathogenesis of several eye diseases, such as ocular surface inflammation and dry eye disease $[19,20]$. So we evaluated, for the first time to our knowledge, the antioxidant and anti-inflammatory activities of polyphenolic fraction obtained from OMWW on SIRC cells.

To test the antioxidant activity, SIRC cells were pretreated with PAD428-FR2 $0.01 \%$ for $24 \mathrm{~h}$ and then were stimulated with $\mathrm{H}_{2} \mathrm{O}_{2}(200 \mu \mathrm{M})$ for 10 and 30 minutes. The results of the MTT assay (Figure 7) showed that $\mathrm{H}_{2} \mathrm{O}_{2}$-treatment reduced cell viability compared to untreated control cell in a time-dependent manner. Moreover, it can be observed that the pretreatment with PAD428-FR2 0.01\% determined an increase in cell viability with respect to $\mathrm{H}_{2} \mathrm{O}_{2}$-treated cells, suggesting a good protective activity of the fraction against the oxidant stimulus. In addition, we performed the alkaline version of the comet assay by using Fpg enzyme that recognizes and cuts the sites corresponding to oxidized guanine bases [37]. The results, shown in Figure 8, evidenced that the pretreatment with PAD428-FR2 $0.01 \%$ was able to protect DNA from oxidative stress induced by $\mathrm{H}_{2} \mathrm{O}_{2}$ added for $30 \mathrm{~min}$.

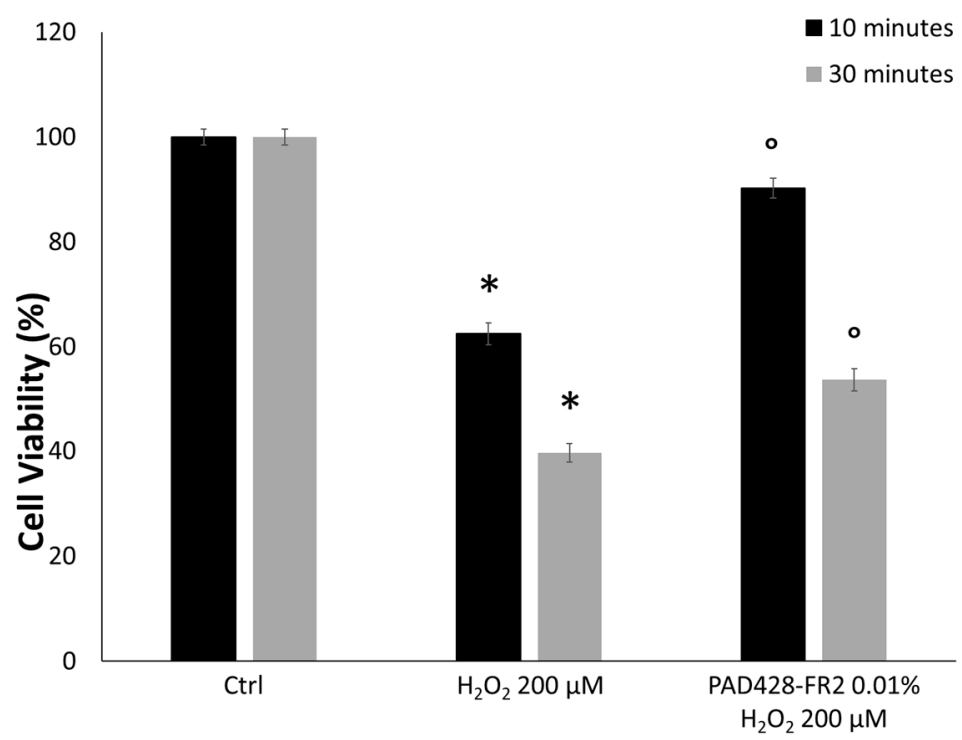

Figure 7. MTT assay performed on SIRC cells pretreated with PAD428-FR2 0.01\% for $24 \mathrm{~h}$ and then stimulated with $\mathrm{H}_{2} \mathrm{O}_{2}(200 \mu \mathrm{M})$ for 10 and $30 \mathrm{~min}$. Untreated cells were used as negative control; cells treated with $\mathrm{H}_{2} \mathrm{O}_{2}(200 \mu \mathrm{M})$ were used as a positive control. The results are expressed as the percentage of cell viability with respect to untreated control cells (Ctrl). Values are mean $\pm \mathrm{SD}$ of three experiments in triplicate. ${ }^{*} p<0.05$ vs. control group; ${ }^{\circ} p<0.05$ vs. $\mathrm{H}_{2} \mathrm{O}_{2}$-treated cells. 


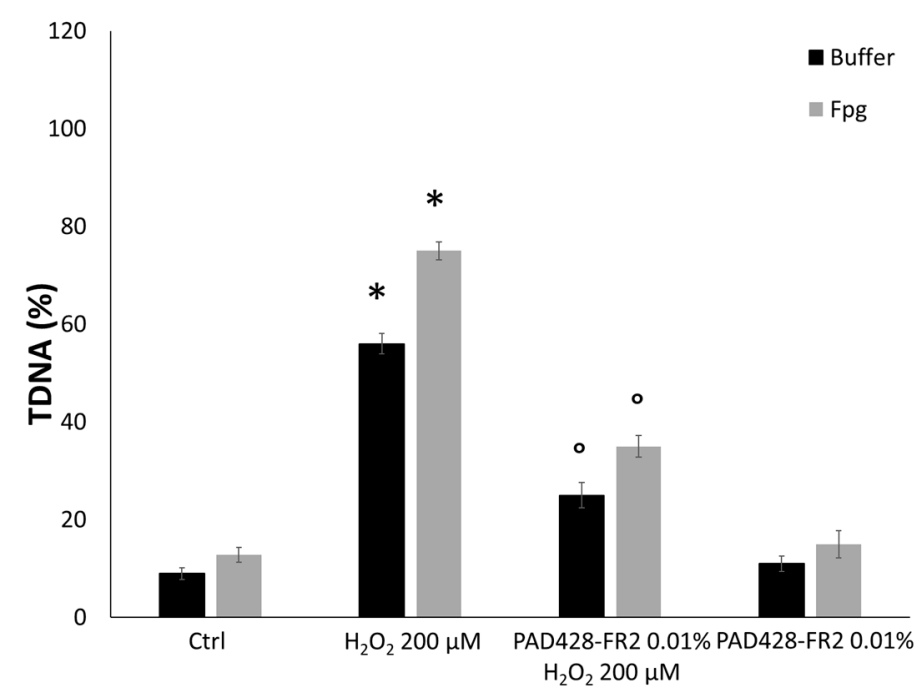

Figure 8. DNA oxidative damage evaluated by Fpg-modified comet assay performed on SIRC cells pretreated with PAD428-FR2 $0.01 \%$ for $24 \mathrm{~h}$ and then stimulated with $\mathrm{H}_{2} \mathrm{O}_{2}(200 \mu \mathrm{M})$ for $30 \mathrm{~min}$. Untreated cells were used as a negative control; cells treated with $\mathrm{H}_{2} \mathrm{O}_{2}(200 \mu \mathrm{M})$ were used as a positive control. The results are expressed as the percentage of DNA present in the comet tail (\%TDNA). Values are mean $\pm \mathrm{SD}$ of three experiments in triplicate. ${ }^{*} p<0.05$ vs. control group; ${ }^{\circ} p<0.05$ vs. $\mathrm{H}_{2} \mathrm{O}_{2}$-treated cells.

As expected, a significant rise of ROS levels was observed in $\mathrm{H}_{2} \mathrm{O}_{2}$-treated cells with respect to untreated control cells in a time-dependent manner. This increase was counteracted by pre-incubating cells with PAD428-FR2 0.01\% (Figure 9).

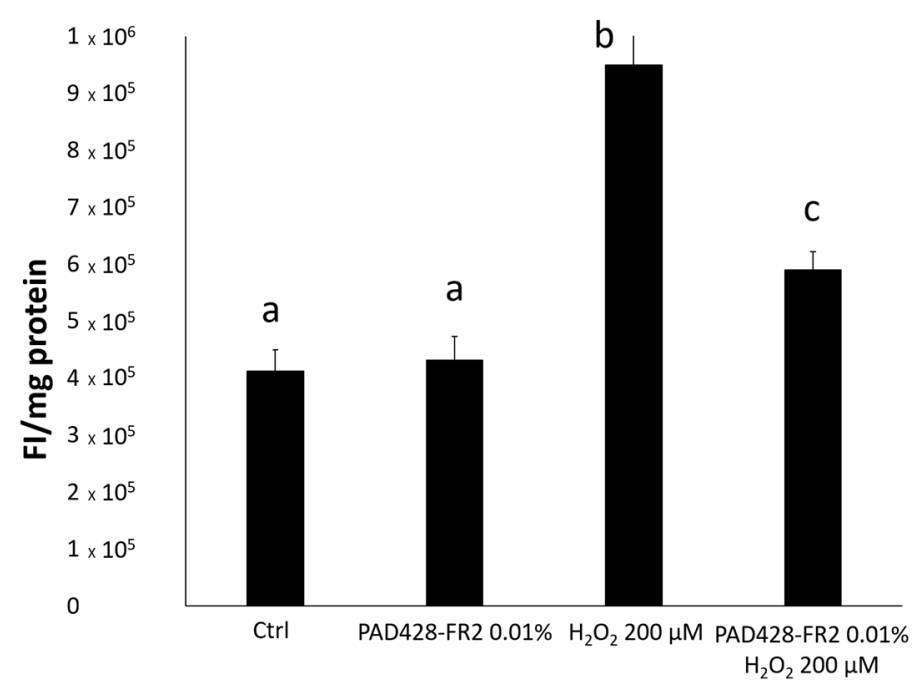

Figure 9. ROS levels evaluated on SIRC cells pretreated with PAD428-FR2 0.01\% for 24 hours and then stimulated with $\mathrm{H}_{2} \mathrm{O}_{2}(200 \mu \mathrm{M})$ for 30 minutes. Untreated cells were used as a negative control; cells treated with $\mathrm{H}_{2} \mathrm{O}_{2}(200 \mu \mathrm{M})$ were used as a positive control. The results were expressed as fluorescence intensity per mg protein. Values are mean \pm SD of three experiments in triplicate. Bars with different letters are significantly different $(p<0.05)$.

Our results are in accordance with Schlupp et al. (2019) who reported the antioxidant activity of a phenol-enriched OMWW extract was able to reduce the formation of free radicals in vitro [52]. Similar results were obtained by Schaffer et al. (2007) who demonstrated that hydroxytyrosol-rich olive mill wastewater extract was able to protect brain cells from oxidative damage [53]. 
Regarding the anti-inflammatory activity, SIRC cells were pretreated with PAD428-FR2 0.01\% for $2 \mathrm{~h}$ and then were stimulated for $24 \mathrm{~h}$ with LPS $(1 \mu \mathrm{g} / \mathrm{ml})$, the major constituent of the outer membrane of Gram-negative bacteria able to elicit inflammation.

As expected, MTT data and immunoblots, shown in Figures 10 and 11, revealed that LPS-treatment significantly reduced the percentage of cell viability and increased the expression of TNF- $\alpha$, a well-known pro-inflammatory mediator involved in ocular inflammation [38]. The results also revealed that the pretreatment with PAD428-FR2 0.01\% determined a marked increase in cell viability and a decrease of TNF- $\alpha$ levels with respect to LPS-treated cells, demonstrating a good protective activity of fraction against the inflammatory stimulus.

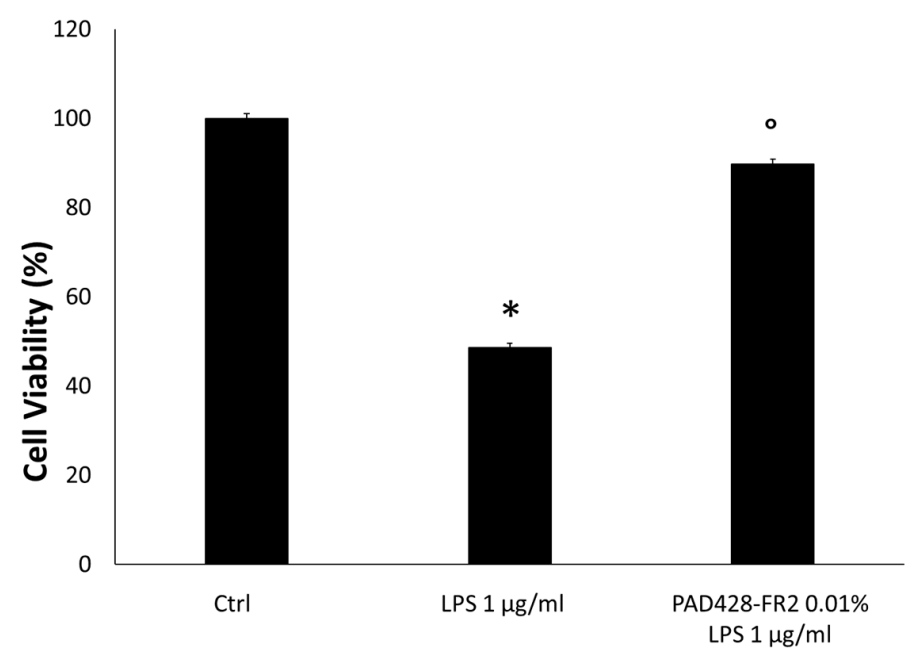

Figure 10. MTT assay performed on SIRC cells pretreated with PAD428-FR2 0.01\% for $2 \mathrm{~h}$ and then stimulated with lipopolysaccharide (LPS) $(1 \mu \mathrm{g} / \mathrm{mL})$ for $24 \mathrm{~h}$. Untreated cells were used as a negative control; cells treated with LPS $(1 \mu \mathrm{g} / \mathrm{mL})$ were used as a positive control. The results are expressed as the percentage of cell viability with respect to untreated control cells (Ctrl). Values are mean \pm SD of three experiments in triplicate. ${ }^{*} p<0.05$ vs. control group; ${ }^{\circ} p<0.05$ vs. LPS-treated cells.

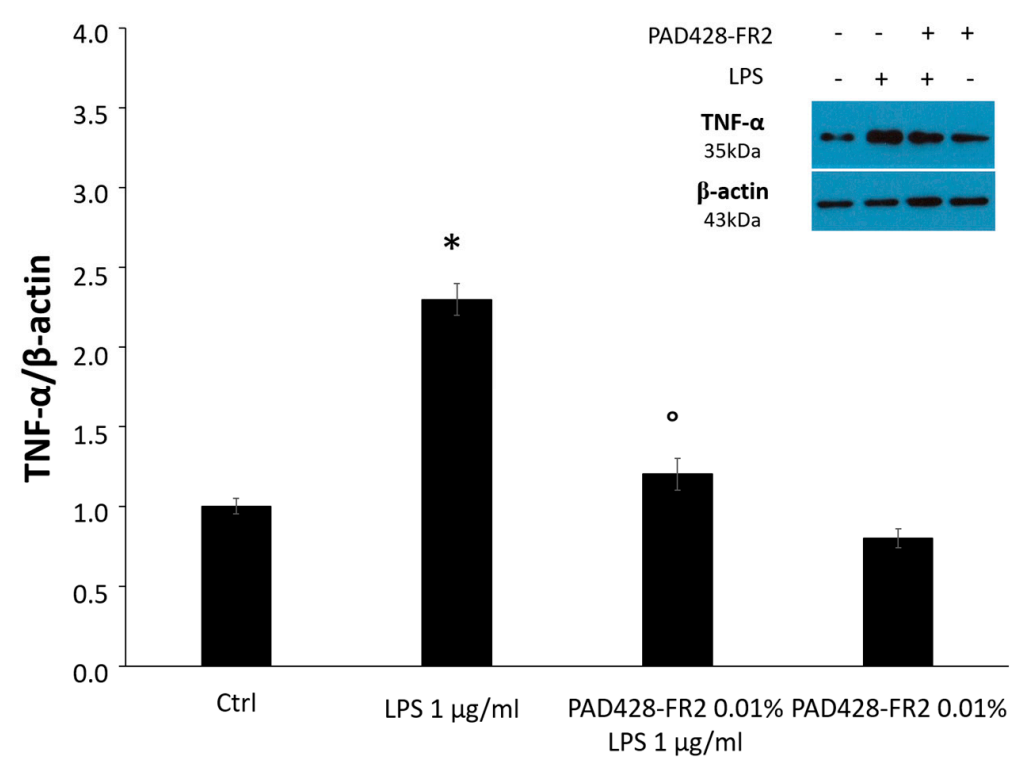

Figure 11. TNF- $\alpha$ levels evaluated by Western Blot analysis performed on SIRC cells pretreated with PAD428-FR2 $0.01 \%$ for $2 \mathrm{~h}$ and then stimulated with LPS $(1 \mu \mathrm{g} / \mathrm{mL})$ for $24 \mathrm{~h}$. Untreated cells were used as a negative control; cells treated with LPS $(1 \mu \mathrm{g} / \mathrm{mL})$ were used as a positive control. $\beta$-actin was used as the loading control. Values are mean $\pm \mathrm{SD}$ of three experiments in triplicate. ${ }^{*} p<0.05 \mathrm{vs}$. control group; ${ }^{\circ} p<0.05$ vs. LPS-treated cells. 
These data are in agreement with several in vitro and in vivo studies; for instance, Baci et al. (2019) reported that a polyphenol-rich extract from olive mill wastewater was able to induce a downregulation of pro-inflammatory pathways in prostate cancer cells [54]. Richard et al. (2011) evidenced that hydroxytyrosol was the major anti-inflammatory compound in aqueous olive extracts able to impair cytokine and chemokine production in murine macrophages stimulated with LPS [18]. In particular, Fuccelli et al. (2018) observed that hydroxytyrosol reduced the TNF- $\alpha$ secretion in LPS stimulated mouse model [17].

Based on the previous biological assays, $0.01 \% w / w$ of lyophilized PAD428-FR2 was used to formulate a novel nutraceutical ophthalmic preparation. Traditional ophthalmic liquid formulations are characterized by limited residence time in the eye due to lacrimal secretion and nasolacrimal drainage resulting in a low drug absorption (only 1-10\%) and limited efficacy. The increase of viscosity of the formulation using biocompatible hydrophilic polymers with mucoadhesive properties represents one of the best strategies to prolong the residence time in the eye $[55,56]$. Indeed, several studies have reported that the water-base gels have several advantages over the traditional ophthalmic formulations, either in terms of enhanced therapeutic response or improved ocular bioavailability [57]. According to these considerations, in this study a combination of different hydrophilic polymers as Carbopol ${ }^{\circledR 9} 90$ and Pemulen ${ }^{\mathrm{TM}}$ RT1-NF was employed to enhance the viscosity and obtain a hydrogel with a 3D polymeric network [58]. Hydrogel was prepared according to the protocol described in the "Materials and Methods" section, and the final composition is shown in Table 1.

The ophthalmic formulation was clear without any suspended particles or impurities and showed a $\mathrm{pH}$ value equal to 6.7 which is considered physiologically compatible. As reported in the Materials and Methods section, the values regarding $\mathrm{pH}$, appearance, osmolality, and hydroxytyrosol (\%) were evaluated to assess the chemical and physical stability in the storage period. The results of stability study, shown in Table 4, revealed no significant changes with respect to hydroxytyrosol concentration (\%), pH, osmolality, and appearance in samples stored at $25 \pm 2{ }^{\circ} \mathrm{C}$ with $60 \% \pm 5 \%$ R.H. for 3 months.

Table 4. Stability study performed on ophthalmic hydrogel stored at $25 \pm 2{ }^{\circ} \mathrm{C}$ with $60 \% \pm 5 \%$ R.H. for 3 months.

\begin{tabular}{lllll}
\hline \multicolumn{5}{c}{ Months } \\
\hline & $\mathbf{0}$ & $\mathbf{1}$ & $\mathbf{2}$ & $\mathbf{3}$ \\
\hline Hydroxytyrosol (\%) & 100 & 99 & 98 & 98 \\
$\mathrm{pH}$ & $6.7 \pm 0.1$ & $6.7 \pm 0.1$ & $6.6 \pm 0.1$ & $6.7 \pm 0.1$ \\
Osmolality & $150.0 \pm 1.0$ & $153.0 \pm 1.0$ & $155.0 \pm 1.0$ & $155.0 \pm 1.0$ \\
Appearance & transparent & transparent & transparent & transparent \\
\hline \multicolumn{5}{l}{ Mean values $(n=9) \pm$ SD were calculated. }
\end{tabular}

Finally, we evaluated the ocular irritation of hydrogel using SkinEthicTM HCE model, composed of human corneal epithelial cells that forms a corneal epithelial tissue when cultured at the air-liquid interface in a chemically defined medium on a permeable synthetic membrane insert [39].

The percentage of cell viability evaluated by MTT assay was equal to $95.7 \pm 5.3$ for tissues treated with hydrogel. According to the viability classification prediction model, since the percentage of viability is more than $60 \%$, the hydrogel can be classified as non-irritant.

\subsection{Scaling up and Pilot Plant Development}

A mandatory feature for a process aiming to be an applicative and possibly marketable development is economic sustainability. In order to evaluate this parameter and with the aim to test the scalability, reproducibility, and effectiveness of our protocols at a pre-industrial scale too, an automatized pilot plant for polyphenols extraction from OMWW was realized by using the optimized laboratory conditions. 
In Figure 12 is the schematized pilot plant consisting of the following steps: de-oiling and sand removal through a settler and an oil-separator, sand filtration, adsorption process through

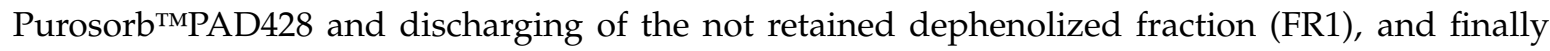
desorption of the polyphenolic mixture (FR2) stored in a $2000 \mathrm{~L}$ accumulation tank by eluting with water \ethanol 50:50. A mixture of ethanol/isopropanol, 85:15, instead of pure ethanol, was used in the desorption phase because it represented the purest composition on the market for semi-industrial use.

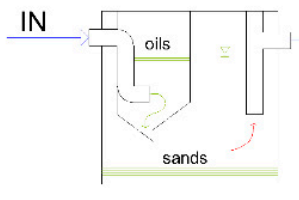

Oil separator $\mathrm{V}=917 \mathrm{I}$

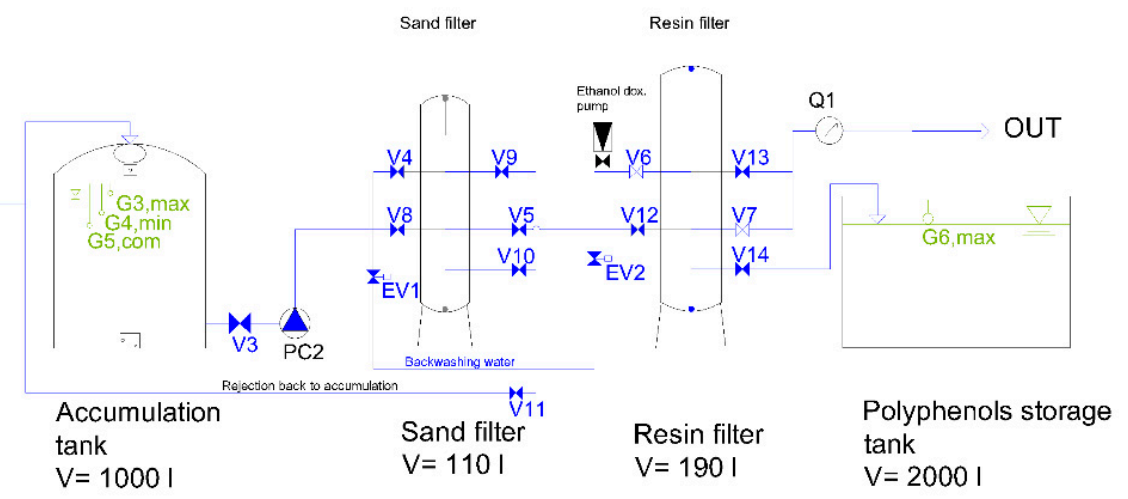

Figure 12. Scheme of the developed pilot plant prototype.

The empty bed contact time, with the operating flow, was about $48 \mathrm{~min}$, a sufficient time to reach the maximum adsorption, according to laboratory results.

Preliminary runs in the pilot plant (see Figure S9 of prototype in Supplementary material) showed that the various fractions have features tending to satisfactorily match the laboratory results but need to be furtherly optimized. This is shown in Table 5, which compares olive mill wastewaters and fractions FR1/FR2 characteristics, obtained from the treatment in the pilot plant. It is to be noted that the difference in composition between lab and scale-up could partly be explained by the different purity of used eluents.

Table 5. Characterization of eluted fractions from preliminary pilot plant tests.

\begin{tabular}{llll}
\hline \multicolumn{1}{c}{ Characterization } & \multicolumn{1}{c}{ OMWW } & \multicolumn{1}{c}{ PAD428-FR1 } & \multicolumn{1}{c}{ PAD428-FR2 } \\
\hline Total Nitrogen $(\mathrm{mg} / \mathrm{L})$ & $350.0 \pm 3.4$ & $204 \pm 1.6$ & $1.0 \pm 0.2$ \\
Total Phosphorous $(\mathrm{mg} / \mathrm{L})$ & $186.0 \pm 2.1$ & $97 \pm 1.4$ & $0.5 \pm 0.1$ \\
COD $(\mathrm{g} / \mathrm{L})$ & $73.65 \pm 1.43$ & $50.60 \pm 1.93$ & $20.42 \pm 1.64$ \\
BOD5 $(\mathrm{g} / \mathrm{L})$ & $38.44 \pm 2.12$ & $19.82 \pm 2.24$ & $15.60 \pm 1.45$ \\
Total Polyphenols $(\mathrm{g} / \mathrm{L})$ & $5.20 \pm 0.14$ & $2.10 \pm 0.09$ & $1.12 \pm 0.08$ \\
Hydroxytyrosol $(\mathrm{g} / \mathrm{L})$ & $1.10 \pm 0.08$ & not detected & $0.45 \pm 0.07$ \\
Tyrosol $(\mathrm{g} / \mathrm{L})$ & $0.14 \pm 0.02$ & not detected & $0.06 \pm 0.01$ \\
Total Sugar $(\mathrm{g} / \mathrm{L})$ & $34.00 \pm 2.18$ & $23.50 \pm 3.11$ & $3.55 \pm 3.38$ \\
\hline
\end{tabular}

Mean values $(n=9) \pm \mathrm{SD}$ were calculated.

The FR1 showed a reduced content in polyphenols (more than 50\%), and a COD abatement of about $32 \%$. This sugar-enriched fraction was used to develop novel cosmeceutical formulations as described in a previous work [30]; alternatively, it is possible to imagine for this fraction a final oxidative stage (aerobic microbial digestion) able to furnish clear depolluted water and, as a secondary product, some sludge that could find easy application as compost in agriculture due to its rich organic content. A further reduction of polyphenols content would help the potential subsequent biological sludge treatment, with the addition of urea and ammonium phosphate, to achieve the correct nutritional balance. After evaporation of the solvent, the residues of the FR2 alcoholic extract were analyzed by HPLC (chromatogram not reported): The main components, analogously to the lab-scale process, were tyrosol and hydroxytyrosol, with an average polyphenolic recovery of $22 \%$, and a hydroxytyrosol 
purity of $40 \%$. The lower polyphenolic recovery value (if compared to laboratory results) needs to be improved and investigations regarding the optimization of the scaling up parameters, especially flow rate and contact time, are actually in progress, but in general these firsts pilot plant operation experiments demonstrated that expected results are not too far from being reached.

In the pilot plant prototype, the total installed power (calculated as the sum of the nominal powers of all power-consuming sections) is about $1 \mathrm{~kW}$, and considering a ten cycle operation, a preliminary economic balance was assessed, as illustrated in Table 6. Operational only costs were included, while any investment cost was excluded. Noteworthy, by recycling ethanol, that represents one of the major costs in the procedure, a substantial reduction of the total cost could be achieved, but one of the main objectives of subsequent studies should be a better regeneration of the resin and/or the extension of its useful life.

Table 6. Economical balance of the pilot prototype for ten-cycle operations.

\begin{tabular}{llll}
\hline \multicolumn{1}{c}{ Cost Item } & Quantity (Units) & Unit Cost $(\boldsymbol{\epsilon})$ & Total Item Cost $(\boldsymbol{\epsilon})$ \\
\hline Adsorbent $(\mathrm{kg})$ & 32 & 38.00 & 1216.00 \\
Ethanol $(\mathrm{L})$ & 500 & 1.80 & 900.00 \\
Manpower (hours) & 2 & 25.00 & 50.00 \\
Wastewater treatment $\left(\mathrm{m}^{3}\right)$ & 2 & 0.80 & 1.60 \\
Energy $(\mathrm{kWh})$ & 15 & 0.10 & 1.50 \\
Mains water $\left(\mathrm{m}^{3}\right)$ & 2 & 0.30 & 0.60 \\
& & Total 10-cycles cost & 2169.70 \\
Average polyphenolic extract production for 10 cycles $(\mathrm{kg})$ & 2 \\
Estimated cost per kg of extract $(€ / \mathrm{kg})$ & 1084.85 \\
\hline
\end{tabular}

\section{Conclusions}

The described approach allows the ability to turn a highly polluting waste into valuable fractions, which can potentially be considered as raw starting materials for pharmaceutical/nutraceutical applications. A pilot plant prototype was realized and a preliminary economic balance calculated, showing the feasibility of the process at a pre-industrial level. In vitro biological assays were performed on the obtained polyphenolic fraction to study its cytotoxicity and anti-inflammatory/antioxidant activities, and the results permitted the ability to formulate a novel ophthalmic hydrogel with promising features that of course need yet to be more deeply characterized in view of a commercialization plan.

Supplementary Materials: The following are available online at http://www.mdpi.com/2076-3921/8/10/462/s1, Table S1: Metals analysis of Cerasuola-OMWW and fractions performed by ICP-MS, Table S2: Biophenols in Cerasuola-OMWW and PAD428-FR2 performed by HPLC-DAD analysis, Figure S1: Pictures of unabsorbed fraction eluted with water (PAD428-FR1, left) and fraction eluted with water/ethanol (50/50) solution (PAD428-FR2, right), Figure S2: Chromatogram of PAD428-FR1 at $280 \mathrm{~nm}$, Figure S3: Chromatogram of PAD900-FR1 at $280 \mathrm{~nm}$, Figure S4: Chromatogram of PAD550-FR1 at $280 \mathrm{~nm}$, Figure S5: Chromatogram of PAD900-FR2 at $280 \mathrm{~nm}$, Figure S6: Chromatogram of PAD550-FR2 at $280 \mathrm{~nm}$, Figure S7: ${ }^{1} \mathrm{H}-\mathrm{NMR}$ spectrum of PAD428-FR1 exhibited only signals in the typical regions of the alkylic (1-2 ppm) and heteroalkylic groups (3-4 ppm), confirming the absence of polyphenols and giving indications about the presence of carbohydrates, Figure S8: ${ }^{1} \mathrm{H}-\mathrm{NMR}$ spectrum of PAD428-FR2 exhibited the characteristic signals of aromatic compounds (around 6.0-7.5 ppm) confirming the aromatic nature of the compounds in the mixture. Alkylic (1-2 ppm) and heteroalkylic groups (3-4 ppm) are still present and can be assigned to the sugar moiety of the glycosylated phenols, Figure S9: Picture of the pilot plant.

Author Contributions: Conceptualization, D.A., R.M., and N.D.; formal analysis, R.M.; funding acquisition, N.D.; investigation, M.D.D.M., G.F., M.S., and G.C.; project administration, N.D.; supervision, N.D.; validation, M.D.D.M., B.M., and M.G.S.; visualization, D.A.; writing—original draft, M.D.D.M. and N.D.; writing-review and editing, M.D.D.M. and N.D.

Funding: This research was funded by CNR (research project 1422 PO FESR Sicilia 2007-2013 linea d'intervento 4.1.1.1).

Acknowledgments: The authors wish to thank Sandro Dattilo and Emanuele Mirabella (National Research Council of Italy, Institute of Polymers, Composites, and Biomaterials, Via Paolo Gaifami 18, 95126 Catania, Italy) for the ICP-MS metal analysis (Supplementary material). 
Conflicts of Interest: The authors declare no conflict of interest.

\section{References}

1. Deeb, A.A.; Fayyad, M.K.; Alawi, M.A. Separation of Polyphenols from Jordanian Olive Oil Mill Wastewater. Chromatogr. Res. Int. 2012, 2012, 812127. [CrossRef]

2. Kapellakis, I.E.; Tsagarakis, K.P.; Crowther, J.C. Olive oil history, production and by-product management. Rev. Environ. Sci. Biol. 2008, 7, 1-26. [CrossRef]

3. Dermeche, S.; Nadour, M.; Larroche, C.; Moulti-Mati, F.; Michaud, P. Olive mill wastes: Biochemical characterizations and valorization strategies. Process Biochem. 2013, 48, 1532-1552. [CrossRef]

4. Allouche, N.; Fki, I.; Sayadi, S. Toward a high yield recovery of antioxidants and purified hydroxytyrosol from olive mill wastewaters. J. Agric. Food Chem. 2004, 52, 267-273. [CrossRef] [PubMed]

5. D'Antuono, I.; Kontogianni, V.G.; Kotsiou, K.; Linsalata, V.; Logrieco, A.F.; Tasioula-Margari, M.; Cardinali, A. Polyphenolic characterization of Olive Mill WasteWaters, coming from Italian and Greek olive cultivars, after membrane technology. Food Res. Int. 2014, 65, 301-310. [CrossRef]

6. Fiorentino, A.; Gentili, A.; Isidori, M.; Lavorgna, M.; Parrella, A.; Temussi, F. Olive oil mill wastewater treatment using a chemical and biological approach. J. Agric. Food Chem. 2004, 52, 5151-5154. [CrossRef] [PubMed]

7. Günay, A.; Çetin, M. Determination of aerobic biodegradation kinetics of olive oil mill wastewater. Int. Biodeter. Biodegr. 2013, 85, 237-242. [CrossRef]

8. Papadimitriou, E.K.; Chatjipavlidis, I.; Balis, C. Application of composting to olive mill wastewater treatment. Environ. Technol. 1997, 18, 101-107. [CrossRef]

9. Fraga, C.G.; Croft, K.D.; Kennedy, D.O.; Tomás-Barberán, F.A. The effects of polyphenols and other bioactives on human health. Food Funct. 2019, 10, 514-528. [CrossRef]

10. Li, A.-N.; Li, S.; Zhang, Y.-J.; Xu, X.-R.; Chen, Y.-M.; Li, H.-B. Resources and biological activities of natural polyphenols. Nutrients 2014, 6, 6020-6047. [CrossRef]

11. Smiljković, M.; Dias, M.I.; Stojković, D.; Barros, L.; Bukvički, D.; Ferreira, I.C.F.R.; Soković, M. Characterization of phenolic compounds in tincture of edible Nepeta nuda: Development of antimicrobial mouthwash. Food Funct. 2018, 9, 5417-5425. [CrossRef] [PubMed]

12. Karković Marković, A.; Torić, J.; Barbarić, M.; Jakobušić Brala, C. Hydroxytyrosol, Tyrosol and Derivatives and Their Potential Effects on Human Health. Molecules 2019, 24, 2001. [CrossRef] [PubMed]

13. Grasso, S.; Siracusa, L.; Spatafora, C.; Renis, M.; Tringali, C. Hydroxytyrosol lipophilic analogues: Enzymatic synthesis, radical scavenging activity and DNA oxidative damage protection. Bioorg. Chem. 2007, 35, 137-152. [CrossRef] [PubMed]

14. Rodríguez-Ramiro, I.; Martín, M.A.; Ramos, S.; Bravo, L.; Goya, L. Olive oil hydroxytyrosol reduces toxicity evoked by acrylamide in human Caco-2 cells by preventing oxidative stress. Toxicology 2011, 288, 43-48. [CrossRef] [PubMed]

15. Maiuri, M.C.; De Stefano, D.; Di Meglio, P.; Irace, C.; Savarese, M.; Sacchi, R.; Cinelli, M.P.; Carnuccio, R. Hydroxytyrosol, a phenolic compound from virgin olive oil, prevents macrophage activation. Naunyn Schmiedebergs Arch. Pharmacol. 2005, 371, 457-465. [CrossRef]

16. Scoditti, E.; Calabriso, N.; Massaro, M.; Pellegrino, M.; Storelli, C.; Martines, G.; De Caterina, R.; Carluccio, M.A. Mediterranean diet polyphenols reduce inflammatory angiogenesis through MMP-9 and COX-2 inhibition in human vascular endothelial cells: A potentially protective mechanism in atherosclerotic vascular disease and cancer. Arch. Biochem. Biophys. 2012, 527, 81-89. [CrossRef] [PubMed]

17. Fuccelli, R.; Fabiani, R.; Rosignoli, P. Hydroxytyrosol Exerts Anti-Inflammatory and Anti-Oxidant Activities in a Mouse Model of Systemic Inflammation. Molecules 2018, 23, 3212. [CrossRef]

18. Richard, N.; Arnold, S.; Hoeller, U.; Kilpert, K.; Wertz, K.; Schwager, J. Hydroxytyrosol is the major anti-inflammatory compound in aqueous olive extracts and impairs cytokine and chemokine production in macrophages. Planta Med. 2011, 77, 1890-1897. [CrossRef]

19. Bucolo, C.; Fidilio, A.; Platania, C.B.M.; Geraci, F.; Lazzara, F.; Drago, F. Antioxidant and Osmoprotecting Activity of Taurine in Dry Eye Models. J. Ocul. Pharmacol. Ther. 2018, 34, 188-194. [CrossRef]

20. Dogru, M.; Kojima, T.; Simsek, C.; Tsubota, K. Potential Role of Oxidative Stress in Ocular Surface Inflammation and Dry Eye Disease. Invest. Ophthalmol. Vis. Sci. 2018, 59, DES163-DES168. [CrossRef] 
21. Xu, Z.; Sun, T.; Li, W.; Sun, X. Inhibiting effects of dietary polyphenols on chronic eye diseases. J. Funct. Foods 2017, 39, 186-197. [CrossRef]

22. Khoufi, S.; Hamza, M.; Sayadi, S. Enzymatic hydrolysis of olive wastewater for hydroxytyrosol enrichment. Bioresour. Technol. 2011, 102, 9050-9058. [CrossRef]

23. Leouifoudi, I.; Zyad, A.; Amechrouq, A.; Oukerrou, M.A.; Mouse, H.A.; Mbarki, M. Identification and characterisation of phenolic compounds extracted from Moroccan olive mill wastewater. Food Sci. Technol. 2014, 34, 249-257. [CrossRef]

24. Leouifoudi, I.; Harnafi, H.; Zyad, A. Olive Mill Waste Extracts: Polyphenols Content, Antioxidant, and Antimicrobial Activities. Adv. Pharmacol. Sci. 2015, 2015, 714138. [CrossRef]

25. Zagklis, D.P.; Vavouraki, A.I.; Kornaros, M.E.; Paraskeva, C.A. Purification of olive mill wastewater phenols through membrane filtration and resin adsorption/desorption. J. Hazard. Mater. 2015, 21, 69-76. [CrossRef]

26. Fava, G.; Di Mauro, M.D.; Spampinato, M.; Biondi, D.; Gambera, G.; Centonze, G.; Maggiore, R.; D’Antona, N. Hydroxytyrosol Recovery from Olive Mill Wastewater: Process Optimization and Development of a Pilot Plant. Clean Soil Air Water 2017, 45, 1600042. [CrossRef]

27. Obied, H.K.; Allen, M.S.; Bedgood, D.R.; Prenzler, P.D.; Robards, K.; Stockmann, R. Bioactivity and Analysis of Biophenols Recovered from Olive Mill Waste. J. Agric. Food Chem. 2005, 53, 823-837. [CrossRef]

28. Di Mauro, M.D.; Giardina, R.C.; Fava, G.; Mirabella, E.F.; Acquaviva, R.; Renis, M.; D’Antona, N. Polyphenolic profile and antioxidant activity of olive mill wastewater from two Sicilian olive cultivars: Cerasuola and Nocellara etnea. Eur. Food Res. Technol. 2017, 243, 1895-1903. [CrossRef]

29. Dubois, M.; Gilles, K.A.; Hamilton, J.K.; Rebers, P.A.; Smith, F. Colorimetric method for determination of sugars and related substances. Anal. Chem. 1956, 28, 350-356. [CrossRef]

30. Di Mauro, M.D.; Tomasello, B.; Giardina, R.C.; Dattilo, S.; Mazzei, V.; Sinatra, F.; Caruso, M.; D’Antona, N.; Renis, M. Sugar and mineral enriched fraction from olive mill wastewater for promising cosmeceutical application: Characterization, in vitro and in vivo studies. Food Funct. 2017, 8, 4713-4722. [CrossRef]

31. Malfa, G.A.; Tomasello, B.; Acquaviva, R.; Genovese, C.; La Mantia, A.; Cammarata, F.P.; Ragusa, M.; Renis, M.; Di Giacomo, C. Betula etnensis Raf. (Betulaceae) Extract Induced HO-1 Expression and Ferroptosis Cell Death in Human Colon Cancer Cells. Int. J. Mol. Sci. 2019, 20, 2723. [CrossRef]

32. Malfa, G.A.; Tomasello, B.; Sinatra, F.; Villaggio, G.; Amenta, F.; Avola, R.; Renis, M. Reactive response evaluation of primary human astrocytes after methylmercury exposure. J. Neurosci. Res. 2014, 92, 95-103. [CrossRef]

33. Tomasello, B.; Malfa, G.A.; Strazzanti, A.; Gangi, S.; Di Giacomo, C.; Basile, F.; Renis, M. Effects of physical activity on systemic oxidative/DNA status in breast cancer survivors. Oncol. Lett. 2017, 13, 441-448. [CrossRef]

34. Di Mauro, M.D.; Ferrito, V.; Scifo, C.; Renis, M.; Tomasello, B. Effectiveness of Natural Compounds on DNA Damage in Coris julis (Linneaus 1758) from a Polluted Marine Area. Water Air Soil Pollut. 2017, 228, 228. [CrossRef]

35. Acquaviva, R.; Sorrenti, V.; Santangelo, R.; Cardile, V.; Tomasello, B.; Malfa, G.; Vanella, L.; Amodeo, A.; Mastrojeni, S.; Pugliese, M.; et al. Effects of extract of Celtis aetnensis (Tornab.) Strobl twigs in human colon cancer cell cultures. Oncol. Rep. 2016, 36, 2298-2304. [CrossRef]

36. Bradford, M.M. A rapid and sensitive method for the quantitation of microgram quantities of protein utilizing the principle of protein-dye binding. Anal. Biochem. 1976, 72, 248-254. [CrossRef]

37. Tomasello, B.; Grasso, S.; Malfa, G.; Stella, S.; Favetta, M.; Renis, M. Double-Face Activity of Resveratrol in Voluntary Runners: Assessment of DNA Damage by Comet Assay. J. Med. Food 2012, 15, 441-447. [CrossRef]

38. Anfuso, C.D.; Olivieri, M.; Fidilio, A.; Lupo, G.; Rusciano, D.; Pezzino, S.; Gagliano, C.; Drago, F.; Bucolo, C. Gabapentin Attenuates Ocular Inflammation: In vitro and In vivo Studies. Front. Pharmacol. 2017, 8, 173. [CrossRef]

39. Rodrigues, F.; Pereira, C.; Pimentel, F.B.; Alves, R.C.; Ferreira, M.; Sarmento, B.; Amaral, M.H.; Oliveira, M.B.P.P. Are coffee silverskin extracts safe for topical use? An in vitro and in vivo approach. Ind Crop. Prod. 2015, 63, 167-174. [CrossRef]

40. Bansal, R.C.; Goyal, M. Activated Carbon Adsorption; CRC Press: New York, NY, USA, 2005.

41. Freundlich, H.M. Over the Adsorption in Solution. J. Phys. Chem. A 1906, 57, 385-470.

42. Calisto, V.; Ferreira, C.I.; Oliveira, J.A.; Otero, M.; Esteves, V.I. Adsorptive removal of pharmaceuticals from water by commercial and waste-based carbons. J. Environ. Manag. 2015, 152, 83-90. [CrossRef] 
43. McCabe, W.L.; Smith, J.C.; Harriot, P. Unit Operations of Chemical Engineering, 7th ed.; Chemical Engineering Series; McGraw-Hill: New York, NY, USA, 2005.

44. Wilson, S.L.; Ahearne, M.; Hopkinson, A. An overview of current techniques for ocular toxicity testing. Toxicology 2015, 327, 32-46. [CrossRef]

45. Olivieri, M.; Cristaldi, M.; Pezzino, S.; Rusciano, D.; Tomasello, B.; Anfuso, C.D.; Lupo, G. Phenotypic characterization of the SIRC (Statens Seruminstitut Rabbit Cornea) cell line reveals a mixed epithelial and fibroblastic nature. Exp. Eye Res. 2018, 172, 123-127. [CrossRef]

46. Cristaldi, M.; Olivieri, M.; Lupo, G.; Anfuso, C.D.; Pezzino, S.; Rusciano, D. N-hydroxymethylglycinate with EDTA is an efficient eye drop preservative with very low toxicity: An in vitro comparative study. Cutan Ocul. Toxicol. 2018, 37, 71-76. [CrossRef]

47. Wroblewska, K.; Kucinska, M.; Murias, M.; Lulek, J. Characterization of new eye drops with choline salicylate and assessment of their irritancy by in vitro short time exposure tests. Saudi Pharm J. 2015, 23, 407-412. [CrossRef]

48. Tomasello, B.; Malfa, G.; Galvano, F.; Renis, M. DNA damage in normal-weight obese syndrome measured by Comet assay. Mediterr. J. Nutr. Metab. 2011, 4, 99-104. [CrossRef]

49. Pu, X.; Wang, Z.; Klaunig, J.E. Alkaline Comet Assay for Assessing DNA Damage in Individual Cells. Curr. Protoc. Toxicol. 2015, 65, 1-11.

50. Rapisarda, V.; Loreto, C.; Ledda, C.; Musumeci, G.; Bracci, M.; Santarelli, L.; Renis, M.; Ferrante, M.; Cardile, V. Cytotoxicity, oxidative stress and genotoxicity induced by glass fibers on human alveolar epithelial cell line A549. Toxicol. In Vitro 2015, 29, 551-557. [CrossRef]

51. Muscoli, C.; Fresta, M.; Cardile, V.; Palumbo, M.; Renis, M.; Puglisi, G.; Paolino, D.; Nisticò, S.; Rotiroti, D.; Mollace, V. Ethanol-induced injury in rat primary cortical astrocytes involves oxidative stress: Effect of idebenone. Neurosci. Lett. 2002, 329, 21-24. [CrossRef]

52. Schlupp, P.; Schmidts, T.M.; Pössl, A.; Wildenhain, S.; Lo Franco, G.; Lo Franco, A.; Lo Franco, B. Effects of a Phenol-Enriched Purified Extract from Olive Mill Wastewater on Skin Cells. Cosmetics 2019, 6, 30. [CrossRef]

53. Schaffer, S.; Podstawa, M.; Visioli, F.; Bogani, P.; Müller, W.E.; Eckert, G.P. Hydroxytyrosol-rich olive mill wastewater extract protects brain cells in vitro and ex vivo. J. Agric. Food Chem. 2007, 55, 5043-5049. [CrossRef]

54. Baci, D.; Gallazzi, M.; Cascini, C.; Tramacere, M.; De Stefano, D.; Bruno, A.; Noonan, D.M.; Albini, A. Downregulation of Pro-Inflammatory and Pro-Angiogenic Pathways in Prostate Cancer Cells by a PolyphenolRich Extract from Olive Mill Wastewater. Int. J. Mol. Sci. 2019, 20, 307. [CrossRef]

55. Ludwig, A. The use of mucoadhesive polymers in ocular drug delivery. Adv. Drug Deliv. Rev. 2005, 57, 1595-1639. [CrossRef]

56. Almeida, H.; Amaral, M.H.; Lobão, P.; Sousa Lobo, J.M. In situ gelling systems: A strategy to improve the bioavailability of ophthalmic pharmaceutical formulations. Drug Discov. Today 2014, 19, 400-412. [CrossRef]

57. Zaki, R.; Hosny, K.M.; Khames, A.; Abd-elbary, A. Ketorolac tromethamine in-situ ocular hydrogel: Preparation, characterization and in vivo evaluation. Int. J. Drug Del. 2011, 3, 535-545.

58. Hoare, T.R.; Kohane, D.S. Hydrogels in drug delivery: Progress and challenges. Polymer 2008, 49, $1993-2007$. [CrossRef]

(C) 2019 by the authors. Licensee MDPI, Basel, Switzerland. This article is an open access article distributed under the terms and conditions of the Creative Commons Attribution (CC BY) license (http://creativecommons.org/licenses/by/4.0/). 